\title{
New Options for State Indirect Purchaser Legislation: Protecting the Real Victims of Antitrust Violations
}

Robert H. Lande

University of Baltimore School of Law, rlande@ubalt.edu

Follow this and additional works at: http://scholarworks.law.ubalt.edu/all_fac

Part of the Antitrust and Trade Regulation Commons, Litigation Commons, and the State and Local Government Law Commons

\section{Recommended Citation}

New Options for State Indirect Purchaser Legislation: Protecting the Real Victims of Antitrust Violations, 61 Ala. L. Rev. 447 (2010)

This Article is brought to you for free and open access by the Faculty Scholarship at ScholarWorks@University of Baltimore School of Law. It has been accepted for inclusion in All Faculty Scholarship by an authorized administrator of ScholarWorks@University of Baltimore School of Law. For more information, please contact snolan@ubalt.edu. 


\title{
AlabAMA LAW REVIEW
}

Volume 61

2010

Number 3

\section{NeW OPTIONS FOR STATE INDIRECT PURCHASER LEGISLATION: PROTECTING THE REAL VICTIMS OF ANTITRUST VIOLATIONS}

\author{
Robert H. Lande*
}

I. THE CORE COMPONENTS OF AN ILLINOIS BRICK REPEALER............451

A. Complete Illinois Brick Repealers............................451

B. IBRs Authorizing Less Than Treble Damages ......................456

C. Extremely Limited Illinois Brick Repealers ......................459

II. OPTIONS INVOLVING STATE ATTORNEYS GENERAL ...............460

III. MAJOR SUPPLEMENTAL ILLINOIS BRICK REPEALER OPTIONS .........465

A. Damage Markup Presumptions and Findings.....................465

B. Proof of Damages Provisions .....................................468

C. Direct/Indirect Purchaser Damages Allocation Provisions........475

D. Additional Provisions ...............................................485

IV. A PROPOSED MODEL ILLINOIS BRICK REPEALER ...................494

In Illinois Brick v. Illinois Co. ${ }^{1}$ the Supreme Court held that, under federal antitrust law, only direct purchasers have standing to sue antitrust violators for damages. ${ }^{2}$ Since most products travel through one or more

* The author extends his grateful thanks to Neil Averitt, Patrick Cafferty, Patricia Connors, Ellen Cooper, Joshua Davis, Alan Fisher, Albert Foer, Jay Hines, Michael Meyerson, Emily Myers, Saira Nayak-Lieb, William Page, Tommy Prud'homme, Barbara Smithers, Robert Steiner, and David Vandeventer for extremely helpful comments on earlier drafts. The author also would like to thank Christine Carey and Joanna Diamond for valuable research assistance. All opinions and mistakes in this Article are, of course, solely those of the author.

1. Ill. Brick Co. v. Illinois, 431 U.S. 720 (1977).

2. Illinois Brick $\mathrm{Co}$. did include narrow exceptions for cost-plus sales, for cases where the direct purchaser is owned or controlled by an indirect purchaser, and for cases where the direct purchaser is part of the violation. In practice these exceptions have not proven to be very important. See ABA SECTION OF ANTITRUST LAW, INDIRECT PURChASER LITIGATION HANDBOOK 13-25 (2007) [hereinafter ABA HANDBOOK]. A related decision, Hanover Shoe v. United Shoe Mach. Corp., 392 U.S. 481 (1968), held that when an antitust violator is sued by direct purchasers, a defendant cannot successfully assert as a defense that the direct purchasers passed on the overcharges to indirect purchasers. 
intermediaries before reaching consumers, ${ }^{3}$ this decision left most true victims of illegal cartels and other antitrust violations without a remedy to compensate them. ${ }^{4}$ Illinois Brick Co. also had the effect of undermining the objective of optimal deterrence of antitrust violations-because direct purchasers ${ }^{5}$ often have a suboptimal incentive to sue, ${ }^{6}$ the Court's decision often allows violators to escape paying significant damages. For this reason firms are insufficiently deterred from committing future violations. ${ }^{7}$

Fortunately, states are able to effectively overturn this decision by passing legislation that gives indirect purchasers within that state the right to collect damages from antitrust violators. ${ }^{8}$ Not surprisingly, many states enacted laws, called Illinois Brick Repealers ("IBRs"), to give indirect purchasers the right to sue when firms violate analogous state antitrust laws. ${ }^{9}$ The majority of states now have some form of IBR. ${ }^{10}$

In recent years, state IBRs have become more visible and important in light of a number of extremely large, successful recoveries made under the laws of those states that have effective IBRs. These have totaled billions of dollars, including the $\$ 335$ million paid by the vitamin cartel to settle private class actions and parens patriae cases brought by twenty-four states' attorneys general on behalf of indirect purchasers who were consumers in

3. Vitamins, for example, typically pass through several intermediaries before reaching their ultimate users. Due to Illinois Brick Co., few vitamins consumers were able to collect damages from the international vitamins cartels for damages under federal law. The implications of this decision for the victims of the largest discovered private cartel in history were enormous because the cartels had raised the prices of most vitamins sold worldwide between 1990 and 1997 by an average of approximately 30\%. See John M. Connor, The Great Global Vitamins Conspiracy: Sanctions and Deterrence (Am. Antitrust Inst., Working Paper No. 06-02, 2006), available at http://www.antitrustinstitute.org/arch ives/files/485.pdf.

4. Indirect purchasers successfully can sue wrongdoers for injunctive relief, but this does not compensate them for past overcharges. See ABA HANDBOOK, supra note 2, at 23-25.

5. For convenience this Article refers to direct and indirect "purchasers" even though sellers also can be victimized by antitrust violations. See, e.g., Mandeville Island Farms, Inc. v. Am. Crystal Sugar Co., 334 U.S. 219 (1948) (holding that sellers can maintain treble damages actions against firms that fixed the prices they paid for goods).

6. While direct purchasers have the legal right to collect damages and often have the best information about market conditions, they may lack sufficient incentives to do so. For example, their motivation to sue can be low when they are able to pass on most or all of the illegal overcharges to the next level in the distribution chain and/or when they fear retaliation in their future business dealings with powerful suppliers. See discussion infra Parts I.A, III.C.

7. Id. For a discussion of optimal deterrence in this context see infra Parts I.A. and note 183. See also Robert H. Lande, Why Antitrust Damage Levels Should Be Raised, 16 LOY. CONSUMER L. REV. 329, 331-39 (2004) [hereinafter Lande, Antitrust Damage Levels], available at http://papers.ssm.com/sol3/papers.cfm?abstract_id =1118902.

8. State legislation was specifically permitted in California v. ARC America Corp., 490 U.S. 93 (1983).

9. See Ronald W. Davis, Indirect Purchaser Litigation: ARC America's Chickens Come Home To Roost On The Illinois Brick Wall, 65 ANTITRUST L.J. 375 (1997).

10. Edward D. Cavanagh, Illinois Brick: $A$ Look Back and A Look Ahead, 17 LOY. CONSUMER L. REV. 1, 19 (2004) (stating that 30 states have an IBR). The precise number depends upon a number of definitional considerations, such as whether state consumer protection statutes that can accomplish similar tasks are counted, and whether state statutes passed prior to Illinois Brick Co. that permit indirect purchaser suits are counted. See ABA HANDBOOK, supra note 2, at 26-28. 
their states. ${ }^{11}$ These settlements ${ }^{12}$ have caused many legislators and others living in states without effective IBRs to consider legislation that would enable indirect purchasers in their state also to have the right to obtain compensation for antitrust injuries. Moreover, many have come to believe that the current overall effective levels of antitrust damages are too low to deter most violations. ${ }^{13}$ New and more effective IBRs would be an additional way to help prevent anticompetitive behavior. For these and other reasons, during the next few years a number of states might want to enact new IBR legislation or pass laws to strengthen their existing IBR. ${ }^{14}$

For a number of reasons not every state has decided, or will decide, to enact IBR legislation. ${ }^{15}$ Moreover, those states that have decided to enact some form of IBR have passed a wide variety of legislation. ${ }^{16}$ This lack of uniformity at the state level can be attributed to a number of causes, including political factors, the interests of local businesses, the desire to avoid wasteful, costly, and lengthy duplicative litigation, ${ }^{17}$ and a state's

11. See Harry First, The Vitamins Case: Cartel Prosecutions and the Coming of International Competition Law, 68 ANTITRUST L.J. 711 (2001). For other recent prominent examples, see Patrick E. Cafferty, Indirect Purchaser Class Action Settlements (Am. Antitrust Inst., Working Paper No. 06-05, 2006), available at http://www.antitrustinstitute.org/archives/files/510.pdf, and Robert H. Lande \& Joshua P. Davis, Benefits From Private Antitrust Enforcement: An Analysis of Forty Cases, 42 U.S.F. L. $\quad$ REV. $879, \quad 899$ tbl.4 (2008), http://papers.ssrn.com/sol3/papers.cfm?abstract_id=1090661.

12. Most recoveries are by settlement, and there have been many settlements of indirect purchaser cases in which overcharged consumers recovered significant damages. See Cafferty, supra note 11 (identifying eighty-four significant successful settlements of indirect purchaser cases, but no final victories).

13. See discussion infra notes 38-39.

14. Some existing state IBRs are quite limited. State IBRs can, for example, only apply to certain industries, only apply to governmental purchasers, or only empower the state Attorney General to file class actions. These are discussed infra Part I.C.

15. Many of the reasons against enacting state IBR legislation are contained in William $\mathrm{H}$. Page, Class Interpleader: The Antitrust Modemization Commission's Recommendation to Overrule Illinois Brick, 53 ANTITRUST BULL. 725 (2008). Professor Page is opposed to indirect purchaser laws for two primary reasons:

First, a pure direct purchaser regime would provide the most efficient means of imposing a deterrent penalty equal to three times the overcharge. . . . Second, even if compensation is an appropriate goal, indirect purchaser suits will not achieve it. We are all indirect purchasers of goods that are more expensive because of antitrust violations; most of us have even received notice that we were members of putative or certified classes. But our harms are too diffuse, too individualized, and too small for the courts to calculate and distribute efficiently. The legal system should focus its energies on imposing the appropriate deterrent penalty for antitrust violations at the lowest possible direct cost.

Id. at 744. See also Cavanagh, supra note 10, at 25-27. Those who oppose state enactment of IBRs tend to focus heavily on the possibility that "duplicative" payments made under federal and state antitrust laws could mean that wrongdoers might have to pay "too much" and that some classes of plaintiffs who were not injured very much will be overcompensated. They also tend to give inadequate attention to the possibility that, overall, there is suboptimal deterrence of antitrust violations and that their proffered system might leave many real victims uncompensated.

16. See ABA HANDBOOK, supra note 2, at app. a, 305-41 (2007).

17. Professor Page correctly observes that, although there are many disagreements, "[a]ll agree . . . that the multiple suits have led to wasteful duplication of litigation." Page, supra note 15, at 728. 
history. ${ }^{18}$ The great variety of existing state IBRs that will be discussed throughout this Article attests to states' needs for individually tailored solutions to their indirect purchaser problems.

Many advantages would of course arise if a national law were enacted to overturn Illinois Brick. ${ }^{19}$ In many respects this would be better than the current system, where many states have no IBR, some have modest or very limited IBRs, and others have strong IBRs. A national solution would increase uniformity, predictability, and economy of litigation. It has been sought many times since the Illinois Brick decision, by a large number of individuals and organizations. ${ }^{20}$ However, to date every one of the numerous attempts to achieve a comprehensive federal solution has failed, perhaps because there has never been a national political consensus as to which provisions such a law should contain, and also because a uniform federal solution would require preempting existing state laws, an extremely controversial political outcome. ${ }^{21}$

In light of this thirty year stalemate on the federal level, this Article will not join the ranks of futile attempts to craft a political compromise that could be enacted nationally. Instead, this Article will focus on reform at the state level, where it is much more achievable. This Article will develop and present a large number of IBR options that will address the spectrum of a jurisdiction's potential needs, a range of choices that could be considered favorably by states deciding to adopt or amend legislation in this area.

This Article first will present a number of variations on the fundamental core provisions of an IBR. Next will follow a number of important specialized provisions a state or the federal government might decide to enact, including options involving a unique role for state attorneys general, direct versus indirect purchaser damages allocation provisions, damages markup presumptions, and provisions concerning standing, class action

18. Id. Professor Cavanagh also stresses the "logistical nightmare for the courts" with accompanying wasteful litigation and delays that the current system can constitute. Cavanagh, supra note 10, at 30 .

19. As Professor Page notes, see Page, supra note 15, it certainly would be desirable if comprehensive federal legislation could be enacted that would simplify and rationalize the existing system. Moreover, it is difficult to find many members of the antitrust community who think highly of the existing framework. See discussion infra note 25.

20. Many attempts have been made to design and secure the passage of such legislation over the years, but all have failed. The most recent prominent attempt was that by the Antitrust Modernization Commission. For a summary of this history, see ABA HANDBOOK, supra note 2, at 5; Cavanagh, supra note 10 , at 3 n.8, 23-25.

21. The failure to enact federal legislation could arise from the fact that there has never been a national consensus as to which provisions such a law should contain, and also because a uniform federal solution could require preempting existing state laws, an extremely controversial outcome. See J. Thomas Prud'homme, Jr. \& Ellen S. Cooper, One More Challenge for the AMC: Repairing The Legacy of Illinois Brick, 40 U.S.F. L. REV. 675, 677 (2006) ("Attempts to broker a compromise among these competing interests have so far failed. Indeed, satisfying all parties may be impossible.") (footnote omitted). 
certification, and proof of damages issues. The Article contains a number of reasonable alternative ways to address these issues, ${ }^{22}$ together with commentary giving the major ${ }^{23}$ effects, advantages, and disadvantages of each. ${ }^{24}$

As its conclusion, the Article shows why a Type I, II, III error analysis is the ideal framework to evaluate proposed legislation in this field. In light of this approach, the Article then proposes the model legislation the framework suggests is optimal. ${ }^{25}$ While the Article makes every attempt to craft a compromise that successfully balances all relevant, competing concerns, this Model Statute is proffered with full knowledge that it will not be appropriate for every state to enact. States for which the proposed Model Statute is not appropriate could, however, consider enacting another of this Article's proposed alternatives. ${ }^{26}$

\section{THE CORE COMPONENTS OF AN ILUINOIS BRICK REPEALER}

\section{A. Complete Illinois Brick Repealers}

An IBR could be enacted for reasons of either compensation or deterrence, or for both reasons. ${ }^{27}$ An overview of these issues' implications for IBRs will be discussed in turn.

Compensation perspective: $:^{28}$ If only direct purchasers are permitted to sue for damages, then the purchasers that ultimately absorbed the over-

22. This Article will not attempt to cover every possible alternative. For simplicity, many of the less important or less likely to be enacted possibilities have been omitted.

23. Many of the topics discussed infra are so important and complex they have been the subject of separate law review articles. Rather than evolve into a treatise, this Article will only summarize the main considerations involved and provide citations to the relevant literature.

24. Most of these options were found either in a survey of existing IBRs or in the academic literature. No attempt was made to analyze in detail every state remedy statute, academic proposal, or relevant state court decision.

25. This Article's proposed Model Illinois Brick Repealer or one of the alternatives suggested in this Article could be enacted on the federal level, as a supplement to state legislation or in a manner that preempts state IBR laws. Since this Article's proposed Model Statute was not crafted with the idea that it might serve as a compromise that could be enacted on the federal level, however, it is not proffered for possible federal enactment.

26. Moreover, if the national political climate for proconsumer legislation becomes especially favorable, one of the Article's proposed alternatives could of course be enacted at the federal level.

27. For evidence that the antitrust laws, including their damages provisions, were enacted both for reasons of compensation and deterrence, see Robert H. Lande, Are Antitrust "Treble" Damages Really Single Damages?, 54 OHIO ST. L.J. 115 (1993) [hereinafter Lande, Single Damages?], available at http://papers.ssrn.com/sol3/papers.cfm?abstract_id = 1134822 .

28. See Associated Gen. Contractors of Cal., Inc. v. Cal. State Council of Carpenters, 459 U.S. $519,530,530$ n.20 (1983) ("The legislative history of the section shows that Congress was primarily interested in creating an effective remedy for consumers who were forced to pay excessive prices by the giant trusts and combinations that dominated certain interstate markets. . . . The original proposal, which merely allowed recovery of the amount of actual enhancement in price, was successively amended to authorize double-damages and then treble-damages recoveries, in order to provide otherwise remediless small consumers with an adequate incentive to bring suit. . . The same purpose was served by the special venue provisions, the provision for the recovery of attorney's fees, and the 
charges from a violation, who are usually indirect purchasers, ${ }^{29}$ will remain uncompensated. The goal of compensating the actual victims of antitrust violations surely is the primary reason why many desire to repeal Illinois Brick. ${ }^{30}$

Optimal Deterrence Perspective: Often optimal deterrence can be achieved best by direct purchaser suits, but other times, indirect purchaser suits can achieve it best. ${ }^{31}$ Direct purchasers usually have "superior information and incentives, and thus were more likely to discover and police antitrust violations." 32 They usually are better positioned than indirect purchasers to detect price fixing and other illegal behavior. They understand the market with the potential antitrust violation better because they deal directly with it, and so are more likely to be able to determine when, for example, prices rose due to cartelization instead of higher costs. Another factor militating for direct purchaser suits is that proof problems multiply when a court attempts to determine what happened to the overcharge as it passed through each succeeding level of the distribution chain. ${ }^{33}$ Trying to sort out who pays how much extra due to an antitrust violation-especially since price affects quantity sold-dramatically raises litigation time and costs, and lowers predictability. All of these factors weigh in favor of having suits by direct purchasers.

There are, however, situations where direct purchasers have little incentive to sue antitrust violators, or little desire to disrupt an existing supply relationship. Direct purchasers often have an ongoing relationship with the violators, who might be the sole suppliers of the products or services in question, and may be reluctant to sue out of fear of retaliation. ${ }^{34}$

elimination of any requirement that the amount in controversy exceed the jurisdictional threshold applicable in other federal litigation."). See generally Harry First, Lost in Conversation: The Compensatory Function of Antitrust Law (2009) (unpublished draft).

29. See Herbert Hovenkamp, The Indirect-Purchaser Rule and Cost-Plus Sales, 103 HARV. L. REV. 1717, 1726 (1990) ("In general, it appears that more of the monopoly overcharge is passed on than absorbed.").

30. See Areeda, infra note 112. Professor Page notes that much of the impetus behind IBRs "rest[s] on the assertion that the policy of Illinois Brick is unfair because it gives a windfall to direct purchasers and denies any recovery to indirect purchasers, particularly consumers, who may have suffered most of the harm." Page, supra note 15, at 740 .

31. For a thoughtful discussion and survey of the empirical evidence on these issues, see Barak D. Richman \& Christopher R. Murray, Rebuilding Illinois Brick: A Functionalist Approach to the Indirect Purchaser Rule, 81 S. CAL. L. REV. 69, 93-97 (2007).

32. Id. at 93-94.

33. See infra Part IIl.C. This does not, of course, in any way imply that indirect purchasers never or only rarely can prove damages reliably. In some cases the task can be simplified, at least for ultimate consumers. Often they can simply compare the price they paid with the illegal conduct against the price they paid without the illegal conduct. Their damages simply consist of the difference between the two purchases. This can be simpler than tracing the amount of the overcharge passed along at each link in the chain of distribution.

34. Ill. Brick Co. v. Illinois, 431 U.S. 720, 746 (1977) ("We recognize that direct purchasers sometimes may refrain from bringing a treble-damages suit for fear of disrupting relations with their suppliers."); see also Richman \& Murray, supra note 31 , at 94. 
Second, at times the direct purchasers can pass most or all of the overcharges to the next level in the distribution chain. ${ }^{35}$ Under circumstances when the direct purchasers lose little or nothing, they have less incentive to file suit. ${ }^{36}$ Moreover, on occasion, the direct purchasers will have an incentive to tacitly collude with the violators and mark up the overcharges, so that the "direct victims" make a profit from the violation! $!^{37}$ As a result, sometimes indirect purchasers will be in a better position to become "private attorneys general."

The fact that the optimal private enforcers sometimes are direct purchasers, but other times are indirect purchasers, is one of the most vexing problems confronting anyone attempting to design legislation in the area. This is exacerbated by the problem that the attorneys involved may be risk averse and unlikely to file and vigorously pursue lawsuits unless they have a reasonably high expectation of success for their clients. If both the attorneys for the direct purchasers and also the attorneys for the indirect purchasers fear that the entire award could go to the type of purchaser they do not represent, neither may file even if the underlying violation is clear. For these reasons any framework that only permits one category of plaintiff (whether direct or indirect purchaser) to collect damages is likely to lead to underdeterrence. By contrast, a system designed to give both direct and indirect purchasers a reasonable expectation of receiving at least some compensation would always give lawyers for the optimal category of plaintiff an incentive to file.

These factors should be considered in light of the belief held by many that the current system of antitrust damages leads, as a practical matter, to damage levels that are inadequate to deter anticompetitive behavior optimally. Some critics point out that even though antitrust violations are supposed to result in treble damages, due to a variety of factors they probably only lead to single damages even in those relatively few cases that are not settled for lower amounts. ${ }^{38}$ Yet, the damages caused by an antitrust viola-

35. See Robert L. Steiner, The Third Relevant Market, 45 ANTITRUST BULL. 719, 745-58 (2000); Hovenkamp, supra note 29 , at 1726-28.

36. Hovenkamp, supra note 29 , at $1727-28$. Moreover, judges and juries may have a visceral resistance to awarding damages to buyers who pass along some or all of an overcharge. Even though the pass-on is legally irrelevant, those who do not specialize in antitrust often cannot quite accept that fact, and this can factor into the damages that ultimately are awarded to the relatively unharmed direct purchasers.

37. Richman \& Murray, supra note 31, at 94-95 ("Some scholars have further argued that the indirect purchaser rule not only fails to deter antitrust violations, but in fact also encourages additional antitrust violations. Because illegal cartels and monopolists can share rents with direct purchasers without explicitly including them in an illegal conspiracy (and threaten to boycott those who bring suit) antitrust violators can manipulate the incentives of the only parties who have standing. ... [This] facilitate[s] tacit cooperation between antitrust violators and direct purchasers that is virtually impossible to punish. . . . Anecdotal evidence further supports this theory, as direct purchasers were important contributors to several recent high-profile illegal cartels.").

38. See Lande, Antitrust Damage Levels, supra note 7. For an analysis of the actual size of antitrust's "treble damages" remedy, see Lande, Single Damages?, supra note 27. These articles conclude 
tion should greatly exceed their harms because not all antitrust violations are detected ${ }^{39}$ It follows that another benefit of IBRs is that, together with the effects of direct purchaser actions, they can help to deter antitrust violations better. It also follows that those who believe there currently is inadequate overall deterrence are reluctant to agree to IBR solutions that risk lowering the total amounts paid by firms that violate the antitrust laws.

People holding these beliefs tend to believe that to deter antitrust violations optimally, an IBR should not permit an offset for damages paid to direct purchasers. ${ }^{40}$ Several existing state IBRs are consistent with the

that even in those relatively few antitrust cases that are litigated all the way to "treble damages," when the amounts awarded are analyzed correctly, they probably are only at most as large as the damages caused by the violations. However, to deter future antitrust violations effectively, treble damages really should be higher than actual damages. Existing antitrust remedy levels should therefore be raised significantly, and indirect purchaser statutes can help do this. For the specific adjustments that should be made to antitrust's nominal "treble damages" awards, see infra note 39.

See also Joseph F. Brodley, Antitrust Standing in Private Merger Cases: Reconciling Private Incentives and Public Enforcement Goals, 94 MicH. L. Rev. 1, 23 n.91 (1995) ("Treble damages do not adjust for these difficulties when the time value of money and other costs are considered. In fact, treble damages turn out to be closer to single damages when current losses, litigation costs, and future recovery are discounted to present value."); Robert Pitofsky, Antitrust at the Tum of the Twenty-First Century: The Matter of Remedies, 91 GEo. L.J. 169, 171 (2002) ("Studies show that treble damages really amount approximately to single damages in most circumstances.").

Some of these adjustments-such as antitrust's lack of prejudgment interest-apply to other areas of law as well. However, others-such as the allocative inefficiency effects of market power-do not occur as often. See infra note 39.

39. See supra note 7. From a deterrence perspective, damages should be significantly more than singlefold to discourage anticompetitive behavior. However, the "treble damages" that currently are paid to direct purchasers should be adjusted by a number of factors to arrive at their true magnitude:

First, damages should be adjusted for the time value of money. . . . Taking this factor into account, by itself, probably means that so-called "treble" damages are really only approximately double damages. The allocative inefficiency harms from market power-the deadweight loss welfare triangle-are a second "net harm to others" from cartels. Yet, they apparently have never been awarded in an antitrust case. This omission is significant. To oversimplify, Judge Frank Easterbrook made a number of standard assumptions and calculated that, due to the omission from damage awards of this factor alone, "' $[\mathrm{t}] \mathrm{reble}$ damages' are really [only] double the starting point of overcharge plus allocative loss. . .."

Lande, Antitrust Damages Levels, supra note 7, at 337-38 (quoting Frank H. Easterbrook, Detrebling Antitrust Damages, 28 J.L. \& ECoN. 445, 455 (1985)) (footnotes and internal quotation marks omitted). These factors continue:

Third, the umbrella effects of market power are another virtually unawarded damage from market power. ... Moreover, there are five more adjustments to the so-called "treble damages" multiplier that should be made to calculate the net harms to others from an antitrust violation. These eight adjustments, combined, show that even those cases that supposedly award "treble damages" probably only really award damages equal to, at most, one times the actual harms caused by the violation. As noted, however, from the perspective of optimal deterrence damages really should be at the threefold level.

Lande, Antitrust Damage Levels, supra note 7, at 338-39 (footnotes omitted).

Thus, an IBR that resulted in a combination of nominal treble damages to direct purchasers and another nominal treble damages to indirect purchasers would only result in an actual total of roughly double damages, not sixfold damages. For this reason, IBRs do not result in duplication or in overdeterrence.

40. There are several state statutes that preclude "duplicative" recovery, but it is difficult to determine whether they are worried about duplication solely on the state level, or duplication between 
foregoing logic and appear to work well. For example, the current Kansas statute, Ch. 50-161(b)-(c), which provides "damages for violation of act," is clear:

(b) Except as provided in K.S.A. 12-205, and amendments thereto, any person who may be damaged or injured by any agreement, monopoly, trust, conspiracy or combination which is declared unlawful by any of the acts contained in chapter 50 of the Kansas Statutes Annotated, relating to unlawful acts, agreements, monopolies, trusts, conspiracies or combinations in restraint of trade, shall have a cause of action against any person causing such damage or injury. Such action may be brought by any person who is injured in such person's business or property by reason of anything forbidden or declared unlawful by this act, regardless of whether such injured person dealt directly or indirectly with the defendant. The plaintiff in any action commenced hereunder in the district court of the county wherein such plaintiff resides, or the district court of the county of the defendant's principal place of business, may sue for and recover treble the damages sustained. In addition, any person who is threatened with injury or additional injury by reason of any person's violation of such acts may commence an action in such district court to enjoin any such violation, and any damages suffered may be sued for and recovered in the same action in addition to injunctive relief. Any suit for injunctive relief against a municipality shall be subject to the provisions of K.S.A. 12-205, and amendments thereto.

(c) In any action commenced under this section, the plaintiff may be allowed reasonable attorney fees and costs. The remedies provided herein shall be alternative and in addition to any other remedies now provided by law. ${ }^{41}$

the state and federal levels. See, e.g., N.Y. GEN. BUS. LAW \$ 340.6 (McKinney 2004) ("[T]he court shall take all steps necessary to avoid duplicate liability ...."); VT. STAT. ANN. tit. 9, § 2465(b) (1999) (same). Do they just apply to claims made by, for example, multiple levels of indirect purchasers against the same defendant? Or would they apply to awards to direct purchasers as well, even if those direct purchasers recover under federal law? If so, suppose that the direct purchasers settled for single damages, rather than treble. Can the indirect purchaser recover anything? Does the direct purchaser claim have to get resolved first to know if the indirect purchaser even has a damages claim (i.e., can the indirect purchaser go to trial while the direct purchaser claim remains pending)? What if the indirect plaintiffs win first and get treble damages: would they get interpleaded into the direct case? What if a defendant wins against the direct purchasers? Would a recovery of anything by an indirect purchaser be "duplicative"?

As these issues suggest, including an "antiduplication" provision raises questions that may never be answered, but easily could undermine victims' incentives to assert their claims.

41. KAN. STAT. ANN. § 50-161(b)-(c) (2005). 
A state that wants to amend its existing laws could do so using a shorter provision. For example, the following material, based in part on the Kansas provision, could be added to a state's antitrust laws:

The plaintiff in any action commenced hereunder may sue for and recover treble the damages sustained. Such action may be brought by any person who is a citizen or resident of this State who is injured in their business or property by reason of anything forbidden or declared unlawful by this Act, regardless whether such person dealt directly or indirectly with the defendant. This remedy is an additional remedy to any other remedies provided by law, and this remedy shall not diminish or offset any other remedy.

It should be noted that this area of damages law is usually described in terms of a concern with the rights of indirect purchasers. Nevertheless, the antitrust laws apply equally to violations by buyers as well as to violations by sellers. ${ }^{42}$ For this reason an IBR should protect indirect sellers as well as indirect purchasers from the harms caused by antitrust violations. Cases involving an illegal single-firm monopsony or a monopsony cartel are much rarer than antitrust violations that involve sellers, but they often are of particular concern to farmers, ranchers, and owners of natural resources. ${ }^{43}$ IBRs should be worded so they apply to all who lose money due to antitrust violations, regardless of whether they are purchasers or sellers. The above provision is worded to accomplish this.

Moreover, a state might wish to clarify that the beneficiaries of its IBR are only those indirect purchasers that are residents of that state. A state IBR should make it clear that the state was only trying to protect its citizens, and that it was not overreaching and attempting to protect every consumer in the United Sates or to regulate all of the commerce in the United States. The immediately preceding alternative is worded to accomplish this goal.

\section{B. IBRs Authorizing Less Than Treble Damages}

An alternative approach would be to authorize indirect purchasers to recover an amount less than treble damages-in addition to the treble dam-

42. See John B. Kirkwood \& Robert H. Lande, The Fundamental Goal of Antitrust: Protecting Consumers, Not Increasing Efficiency, 84 NOTRE DAME L. REV. 191, 212 (2008), available at http://papers.ssrn.com/sol3/papers.cfm?abstract_id =1113927.

43. See, e.g., Pease v. Jasper Wyman \& Son, 845 A.2d 552 (Me. 2004). This case involved a conspiracy to suppress the prices that were paid for wild blueberries. The jury calculated that the cartel caused a $\$ 56$ million underpayment to the growers. See generally Kirkwood \& Lande, supra note 42 . 
ages received by direct purchasers under the federal antitrust laws. ${ }^{44}$ While these approaches would not provide as much deterrence as one providing treble damages, it is a compromise that could be more politically acceptable. There are a number of alternatives that would accomplish this.

1. Permit indirect purchasers to recover single damages and reasonable attorney fees, in addition to the treble damages recovered by direct purchasers:

The Nebraska antitrust statute, $\S 59-821$ provides:

Any person who is injured in his or her business or property by any other person or persons by a violation of sections 59-801 to $59-831$, whether such injured person dealt directly or indirectly with the defendant, may bring a civil action ... and shall recover actual damages .... and the costs of suit, including a reasonable attorney's fee. ${ }^{45}$

Variations of this approach also are used in Arkansas and Oregon. ${ }^{46}$

2. Allow indirect purchasers to receive mandatory single damages, and permit the court, in its discretion, to award treble damages instead. This remedy would be in addition to any award given to direct purchasers. For example:

Any person who is injured in his or her business or property by any other person or persons by a violation of this Section, whether such injured person dealt directly or indirectly with the defendant, may bring a civil action and shall recover actual damages and the costs of suit, including a reasonable attorney's fee. The Court shall have the discretion to award treble damages to anyone filing suit under this Section [if the Court finds this would be in the interests of justice] [if the violators engaged in willful or flagrant conduct].

This compromise might be politically acceptable in some jurisdictions. It would, however, lead to less deterrence than an approach allowing indirect purchasers to sue for treble damages. It also would have less predictability than an IBR which provides that damages automatically will be

44. An extreme version of these alternatives would require that the total recovered by both direct and indirect purchasers total treble damages; i.e., there would be no increase. For example, the alternatives discussed in Part I.A, supra, could accomplish this if the antiduplication provisions were omitted.

45. NEB. REV. STAT. ANN. \& 59-821 (LexisNexis 2004).

46. ARK. CODE ANN. § 4-75-315(b)(1) (2009); OR. REV. STAT. § 646.545 (2007). 
trebled, and the uncertainty over whether a prevailing plaintiff would receive single or treble damages would cause plaintiffs to be less likely to file suit. Variations of this approach were perhaps enacted with the goal of guiding judicial discretion; existing state legislation provides that indirect purchasers will receive single damages unless the violators engaged in "willful or flagrant [conduct]" (Texas) ${ }^{47}$ or have a "malicious intent to injure" (Massachusetts) ${ }^{48}$ However, apparently no court has ever used its discretion to award treble damages in these situations. For this reason, as a practical matter this type of solution would be similar to one that awards only single damages.

3. Permit indirect purchasers to sue for single damages and also award prejudgment interest. This would be a remedy in addition to those available to direct purchasers.

By analogy, Texas does not permit indirect purchaser suits, but does provide: "Any person ... may sue any person ... and shall recover actual damages sustained, interest on actual damages for the period beginning on the date of service of such person's pleading . . . ${ }^{49}$ The ABA's February 2004 discussion draft also included the provision that rule of reason violations should result in single damages plus prejudgment interest. $^{50}$ The AMC considered this possibility at length, but in the end rejected this option. ${ }^{51}$

An award of single damages plus prejudgment interest would not provide as much deterrence as treble damages. Depending upon the length of the antitrust violation, the length of the trial, and the prevailing interest rate, this provision might increase the total award by roughly twenty to thirty percent. ${ }^{52}$ Even though this is much less than treble damages, a state legislature that believed a new law allowing indirect purchasers to sue for treble damages would constitute excessive deterrence or duplication might instead be willing to enact legislation allowing single damages plus prejudgment interest.

47. TEX. BuS. \& COM. CODE ANN. $\$ 15.21$ (a)(1) (Vernon 2002) ("[I]f the trier of fact finds that the unlawful conduct was willful or flagrant, it shall increase the recovery to threefold the damages sustained and the cost of suit, including a reasonable attorney's fee . . . ").

48. MASS. GEN. LAwS ch. 93, § 12 (2006).

49. TEX. BuS. \& COM. CODE ANN. $\$ 15.21$ (a)(1) (Vernon 2002).

50. See American Bar Association's Antitrust Remedies Task Force Legislative Proposal, Discussion Draft (Feb. 2004) [hereinafter ABA Discussion Draft].

51. ANTITRUST MODERNIZATION COMM'N, REPORT AND RECOMMENDATIONS 246 (2007) [hereinafter AMC REPORT], available at http://govinfo.library.unt.edu/amc/report_recommendation lamc_final_report.pdf.

52. There is evidence showing that the average cartel lasts for roughly seven to eight years and prejudgment litigation requires another four to five years. See Lande, Single Damages?, supra note 27, at 130-34 (computing the lost prejudgment interest due to these time lags). However, in recent years this time lag has had less impact due to current low interest rates. 
4. Permit indirect purchasers in per se cases to recover treble damages and permit indirect purchasers in rule of reason cases to recover single damages.

This would be a different type of compromise. ${ }^{53}$ Even though both per se and rule of reason offenses ${ }^{54}$ harm consumers, this compromise posits that potential per se violators are more likely to be on notice that they are about to commit an antitrust violation, and for this reason it seems fairer to penalize them more. Moreover, per se violations are unquestionably anticompetitive and should be deterred more vigorously than rule of reason violations. A disadvantage of this approach, however, is that there is no clear line between per se and rule of reason violations, ${ }^{55}$ so this approach could lead to less predictability for businesses and consumers. ${ }^{56}$ This uncertainty also could lead to fewer suits being filed and therefore to less deterrence than an approach that awarded treble damages for all violations.

This approach is used in Colorado for indirect government purchasers, ${ }^{57}$ and it was suggested for discussion by the ABA Damages Task Force in February $2004 .{ }^{58}$

\section{Extremely Limited Illinois Brick Repealers}

A much more limited approach would be to repeal Illinois Brick only for extremely narrow or specific purposes, such as only for the indirect purchasers in specific industries. For example, Maryland recently enacted the following IBR, which is among the most limited in the nation:

53. See ABA Discussion Draft, supra note 50.

54. For a general discussion of the differences between per se and rule of reason violations see LaWrence A. Sullivan \& Warren S. Grimes, The LaW of antitrust: AN INTEGRated HANDBOOK 202-17 (West Group ed., 2000).

55. See Cal. Dental Ass'n v. F.T.C., 526 U.S. 756 (1999). The per se/rule of reason quagmire could even be exacerbated by this type of provision. If a law awarded treble damages for per se cases and single damages for rule of reason cases, judges might treat cases under the rule of reason if they believe that treble damages are excessive. This could distort the development of the law and compound the difficulties of plaintiffs in establishing liability.

56. It might be possible to specify by legislation which offenses would merit treble damages. But limiting treble damages to, for example, "horizontal price fixing," "horizontal behavior that directly affects prices," or "horizontal behavior that has many of the characteristics of price fixing" would give rise to disputes over what these terms mean and to which cases these terms apply.

57. Colorado Antitrust Act of 1992, Colo. Rev. STAT. \& 6-4-111(2) (2002).

58. The ABA Discussion draft, supra note 50, reads:

Section 4 of the Clayton Act, 15 U.S.C. $\S 15$, is amended in subsection (a) by adding after "shall recover" the following:

(i), for injuries by reason of anything that is found to be a per se violation of the antitrust laws, threefold the damages by him sustained, and the cost of suit, including a reasonable attorney's fee, and (ii), for injuries by reason of anything else that is forbidden by the antitrust laws, the damages by him sustained thereby, interest thereon computed from the date [on which suit is filed] [on which such injury is sustained] at a rate that will provide the present value of such damages, and the cost of suit, including a reasonable attorney's fee. 
In any action brought by the Attorney General . . . a person that sells, distributes, or otherwise disposes of any drug, medicine, cosmetic, food, food additive, or commercial feed . . . or medical device:

(1) May not assert as a defense that the person did not deal directly with the person on whose behalf the action is brought; and (2) May prove, as a partial or complete defense against a damage claim, in order to avoid duplicative liability, that all or any part of an alleged overcharge ultimately was passed on to another person by a purchaser or seller in the chain of manufacture, production, or distribution who paid the alleged overcharge..$^{59}$

Thus, in Maryland indirect purchasers of drugs, etc. can recover, but only if the Maryland Attorney General files suit, and defendants are permitted to assert a Hanover $S h o e^{60}$ defense that the alleged victims passed along the overcharge to the next level in the distribution chain.

It is difficult to justify confining an IBR to just a single industry. If it makes sense to permit consumer victims who purchase indirectly from pharmaceutical cartels to sue for damages, it also should make sense to give this right to similarly situated victims of other cartels. Nevertheless, an IBR proposal might receive more political support in some States if it were narrowly tailored towards the goal of helping consumers in certain situations, such as the case of senior citizens and others who pay large pharmaceutical and related medical costs. This type of legislation might be introduced as a part of sectoral legislation rather than be advanced as a separate antitrust bill.

Other types of narrow IBR legislation could empower individuals but not classes to sue ${ }^{61}$ could create a remedy for consumer-victims but not for business-victims, or could only permit overcharged government units to recover. ${ }^{62}$

\section{OPTIONS INVOLVING STATE ATTORNEYS GENERAL}

There is a widespread belief that some plaintiffs' attorneys, especially those filing consumer class action suits, ${ }^{63}$ bring irresponsible suits for the

59. MD. Code ANN., HeAlTH-GEN. $\$ 21-1114$ (LexisNexis Supp. 2008).

60. See Hanover Shoe v. United Shoe Mach. Corp., 392 U.S. 481 (1968).

61. The New York law might be limited in this way. See Donnelly Act, N.Y. GEN. BUS. LAw $\S 340.6$, as interpreted by Sperry v. Crompton Corp., 863 N.E.2d 1012, 1017 (N.Y. 2007).

62. See, e.g., MD. CODE ANN., COM. LAW § 11-209(b)(2)(ii) (LexisNexis 2005).

63. F.T.C. Commissioner J. Thomas Rosch, testifying before the Antitrust Modernization Commission Conference on June 8, 2006, opined: "Treble Damage Class Actions. . . . In the real world, they are almost as scandalous as the price-fixing cartels that are generally at issue in the cases. The plaintiffs' lawyers who play in this game . . stand to win almost regardless of the merits of the case." 
purpose of extorting unjustifiable recoveries from defendants. They are sometimes said to negotiate sweetheart settlements that result in relatively worthless coupons or discounts, or trivial refunds to injured consumers, while generating very large attorneys' fees. ${ }^{64}$ In theory, judges are supposed to prevent this type of abuse. Unfortunately, judges do not always have the necessary time or expertise to do this effectively. A state which believed this to be a serious concern might decide to enact an IBR that only permits its attorney general to file indirect purchaser suits. An alternative would be to give the state attorneys general some oversight role in the private suits that are filed. This type of provision would help bring a neutral, well-informed, consumer-oriented party into the situation.

A drawback to this approach is that many or most state attorneys general would not have the resources to detect and pursue these cases often enough to protect their citizens adequately and deter most antitrust violations. Moreover, this exclusivity could put additional political pressures on attorneys general. Attorneys general have considerable discretion over which cases to bring, and their decision to bring or not bring a case opens them to charges of political favoritism. Attorneys general can better protect themselves against this charge if they can point out that aggrieved parties have the right to bring their own antitrust cases. If only the attorneys general can bring cases, they might be more subject to pressure to bring bad cases when important groups argue that they have no other recourse. Attorneys general could also face pressure not to bring cases on behalf of unpopular groups, or groups that supported a different political party.

Regardless of the extent to which these considerations are correct, this Part contains a number of IBR options that highlight the authority and role of the state attorneys general.

1. Only permit the state attorney general to sue, by the use of a parens patriae action, on behalf of any aggrieved indirect purchasers in their state.

J. Thomas Rosch, Comm'r, Fed. Trade Comm'n, Remarks at the ABA Antitrust Modernization Commission Conference (June 8, 2006), available at http://www.ftc.gov/speeches/rosch/RosenAMC\%20Remarks.June 8. final.pdf, at 9-10.

64. See Lande \& Davis, supra note 11, at 884. Despite this widespread belief, there is no evidence that these abuses occur a significant percentage of the time. For evidence that more than $\$ 18$ billion in cash was returned to victims of antitrust violations through private litigation, see id. passim.

Moreover, plaintiffs' attorneys might respond that preventing private suits would be a counterintuitive remedy for the perceived problems. To protect consumers from receiving too little based on the allegedly deficient work of private counsel, private counsel are prevented from obtaining any benefit at all for consumers! Plaintiffs' counsel likely would counter that allowing state attorneys general to bring cases in addition to any private actions, and allowing them to intervene in private actions to protect class members, would be a much better solution. 
Most state attorneys general have parens patriae authority to sue generally on behalf of victimized consumers within their states. For example, the Hawaii Antitrust Statute provides:

The attorney general ... may bring a class action on behalf of consumers based on [violations of this Section]. Actions brought under this subsection shall be brought as parens patriae on behalf of natural persons residing in the State, to secure threefold damages for injuries sustained by such natural persons to their property by reason of any violation of this chapter. ${ }^{65}$

However, defendants in actions brought under some state antitrust statutes might argue that this authority does not exist in their state. It therefore could be desirable for states where this authority is in doubt to enact a law similar to the one in effect in Hawaii. More specifically, a state could enact a law making it clear that this parens patriae authority can be invoked on behalf of indirect purchasers. For example, the Nevada Unfair Trade Practices statute provides that:

The attorney general may bring a civil action for any violation of the provisions of this chapter ... [a]s parens patriae of the persons residing in this state, with respect to damages sustained directly or indirectly by such persons, or . . . as a representative of a class . . . of persons . . . who have been damaged directly or indirectly ... ${ }^{66}$

2. Permit the state attorney general to sue, but only when the state or a local government is the indirect purchaser.

For example, the Arkansas Unfair Practices Statute provides, in § 475-212, civil actions and settlements by the attorney general:

(a) In addition to the other remedies provided in this subchapter, whenever the Attorney General has reason to believe that any person is engaging, has engaged, or is about to engage in any act or practice declared unlawful by this subchapter, the Attorney General may bring an action in the name of the state against that person ... [ [and is authorized]

(3) To recover on behalf of the state and its agencies actual damages or restitution for loss incurred either directly or indirectly; and ... 
(1)(A) The circuit court shall award the Attorney General as monetary relief actual damages sustained or restitution for loss incurred as a result of the violations of this subchapter, and the cost of suit, including a reasonable attorney's fee. ${ }^{67}$

In some states there might be no chance of passing a general repealer. A narrow repealer, limited to overcharges on government purchases, might be the best IBR that could be enacted, at least at a particular time. Note that the Arkansas statute, above, only provides for single damages in these situations.

3. Permit individual indirect purchasers to sue for damages, but not permit class action suits by indirect purchasers, except by the state Attorney General acting on behalf of consumers.

Illinois law provides:

No provision of this Act shall deny any person who is an indirect purchaser the right to sue for damages. Provided, however, that in any case in which claims are asserted against a defendant by both direct and indirect purchasers, the court shall take all steps necessary to avoid duplicate liability for the same injury including transfer and consolidation of all actions. Provided further that no person other than the Attorney General of this State shall be authorized to maintain a class action in any court of this State for indirect purchasers asserting claims under this Act. ${ }^{68}$

This option could be adopted if many within a state believed that abuses by plaintiff's class action attorneys were particularly rampant in situations involving class action cases. In cases involving individual plaintiffs, by contrast, the purchasers are more likely to prevent counsel from engaging in the more egregious types of abuses that allegedly occur, such as settling for worthless coupons plus large attorneys' fees.

A problem with this approach, however, is that it is likely to result in under-enforcement. An individual plaintiff's damages, especially when the purchasers are consumers, often would be far too small to justify filing a lawsuit. While some large businesses might purchase enough pharmaceuticals, vitamins, or computer software to justify filing a lawsuit, it could be rare for small businesses or consumers to do so. Many believe that a ban on private class action suits renders an IBR almost useless. ${ }^{69}$

67. ARK. CODE ANN. \$\$ 4-75-212(a)(3), (b)(1)(A) (Supp. 2009).

68. 740 Ill. Comp. Stat. ANN. 10/7(2) (West Supp. 2009).

69. See the analysis presented by Jay L. Himes, Chief, Antitrust Bureau, Office of the Att'y Gen. of the State of N.Y., Protecting -and Advancing-Consumer Interests: When the Antitrust "Reform" Engine Kicks Into Gear (Nov. 5, 2003), available at http://www.antitrustinstitute.org/archives/files/2 
4. Permit private suits, but make the State Attorney General a potential or mandatory advisor in consumer class action cases:

Plaintiffs shall notify the attorney general about the filing [alternatively, the certification] of any class action containing purchasers from that State that involves antitrust allegations. All parties in these cases shall send copies of all filings in these cases to the attorney general. The attorney general may, at his or her discretion, intervene or file an amicus brief that gives the presiding Judge his or her opinion as to the appropriateness of any proposed settlement of the case.

The Texas statute contains a variation of this, in $\S 15.21(\mathrm{c})$ :

Any person or governmental entity filing suit under this section shall mail a copy of the complaint to the Attorney General of Texas. The attorney general as representative of the public may intervene in the action .... The penalty for failure to comply with this subsection shall be a monetary fine not in excess of $\$ 200 .^{70}$

This provision could give the state attorney general an explicit and perhaps crucial advisory role in private antitrust class action direct purchaser and/or indirect purchaser suits. Currently, some attorneys general can offer advisory opinions in antitrust cases, but this is not commonly done. This provision would facilitate and encourage their commenting and intervening. It would also make the parties conscious that their settlements might be second-guessed by their state attorney general, and this could have beneficial effects. This type of provision ${ }^{71}$ could give the attorney general the option of giving an opinion as to the adequacy of any settlement to the presiding judge. Moreover, the Class Action Fairness Act already mandates this type of notification for a large percentage of class action cases. ${ }^{72}$ A problem with making this comment procedure mandato-

82.pdf, at 19-23.

70. TEX. BUS. \& COM. CODE ANN. \& 15.21(c) (Vernon 2005).

71. Id. The $\$ 200$ fine in the Texas statute cited above, however, is not likely to have much effect. A substantial increase would seem warranted.

72. See 28 U.S.C. $\$ \S 1446,1715$ (2005). With few exceptions, consumer indirect purchaser cases will only be viable as class actions. The Class Action Fairness Act of 2005 (amending 28 U.S.C. $\$ \S 1332,1453$ ) expanded the basis for removing class actions from state court, and currently very few indirect purchaser class actions will be able to proceed in state court. Accordingly, state courts will have very few opportunities to shape the interpretation of state IBRs. States should keep in mind that the IBRs they enact are likely to be interpreted mostly by federal courts, which will involve a "through the looking glass" attempt to guess how state courts would rule in cases that they are now never going to see. Alternatively, interpretation questions sometimes could be certified to the state's highest court. 
ry, however, would be that many or most states would not have the necessary resources to analyze very many class action cases carefully.

\section{MAJOR SUPPLEMENTAL ILLINOIS BRICK REPEALER OPTIONS}

\section{A. Damage Markup Presumptions and Findings}

The size of the markup or overcharge caused by an antitrust violation often changes as it is passed along in the distribution chain. ${ }^{73}$ Just as it usually is difficult to determine which level in the distribution chain absorbed what percentage of the illegal overcharges, it is similarly difficult to determine whether and how these overcharges to the direct purchasers change as they pass on to successive levels of indirect purchasers.$^{74}$ Do direct purchasers ever absorb all or most of the increase? Does a markup by a cartel usually get passed along dollar for dollar to the next level? Or do markups get passed along on a percentage basis? ${ }^{75}$ Or is the passthrough rate somewhere in between a dollar markup and a percentage markup? For example, suppose wholesalers normally charge $\$ 1.00$ and their retailers normally charge consumers $\$ 2.00$. When a wholesale cartel raises its prices from $\$ 1.00$ to $\$ 1.20$, do the retailers on average raise their prices from $\$ 2.00$ to $\$ 2.20$, to $\$ 2.40$, or to some figure in-between $\$ 2.20$

73. For an insightful analysis of many related issues, see Hovenkamp, supra note 29, passim.

74. As Judge Posner observed, "[t]racing a price hike through successive resales . . . is famously difficult." In re Brand Name Prescription Drugs, 123 F.3d 599, 605 (7th Cir. 1997). But see Roger D. Blair \& Jeffrey L. Harrison, Reexamining the Role of Illinois Brick in Modern Antitrust Standing Analysis, 68 GEO. WASH. L. REV. 1, 29 (1999). If a group of manufacturers were to fix prices on goods sold to fabricators who sell to distributors who sell to retailers who sell to consumers, estimating the amount passed on at each stage would be a daunting task. An indirect purchaser, however, need not do this. An indirect purchaser must estimate only the "but for" price that it should have paid, which is a far less exacting exercise than apportioning the overcharge throughout the entire chain of distribution.

75. Robert Steiner shows that when there is a uniform upstream price increase, retailers (and wholesalers) reliably pass through more than the upstream dollar overcharge. For example, when a manufacturer cartel raises prices to retailers by $\$ 1.00$, their retailers typically raise prices to consumers by more than $\$ 1.00$. (By contrast, when upstream firms hike prices by different amounts, the passthrough can be less than, or more than, $100 \%$ of the cartel's price increase). Steiner demonstrated this by analyzing the cigarette industry. In 1998, the tobacco industry reached a far-reaching deal with the states requiring cigarette manufacturers to make large annual contributions to the States to fund various antismoking programs. This caused cigarette makers to boost their prices. All producers uniformly followed Philip Morris's price hikes. Prior to these manufacturers' price increases, the trade margin (wholesaler plus retailer margins) was about $17 \%$. Steiner showed that after several annual factory price increases, the trade margin remained almost $17 \%$. Thus, the combined factory price increases of an average of 63 cents per pack caused retail cigarette prices to rise by an average of 76 cents per pack. See Robert L. Steiner, The Third Relevant Market, 45 ANTITRUST BuLL. 719, 745-58 (2000).

See also Michael P. Lynch, Why Economists Are Wrong to Neglect Retailing and How Steiner's Theory Provides an Explanation of Important Regularities, 49 ANTITRUST BULL. 919, 939 (2004). Dr. Lynch analyzes Steiner's cigarette study plus other examples, including his own empirical research. From this he develops a formal model which "implies that general upstream cost increases will always be passed through to consumers at a rate of more than $100 \%$." 
and $\$ 2.40$ ? In other words, does an initial cartel markup of $20 \mathrm{c}$ grow to $40 c$, stay at $20 \mathrm{c}$, or does it decrease to $10 \mathrm{c}$ as its impact is felt along the distribution chain?

The calculation of the amounts of the markups and their allocation between different types or levels of purchasers currently is done on a caseby-case basis. An alternative has been suggested in the 2008 European Union White Paper on Damages, which contains a presumption ${ }^{76}$ that the entire overcharge is passed on to end users. ${ }^{77}$ A similar presumptionwhich could be rebuttable or conclusive-could, in appropriate United States cases, save litigation costs and time, increase business certainly, and optimally provide potential plaintiffs with a sufficient incentive to sue the violators.

Moreover, without this type of presumption it can be especially difficult for injured plaintiffs to demonstrate the amount of the passed through overcharge when the overcharge only affected a component or ingredient. The effects are often very difficult to trace, especially when the component is only a modest part of the cost of the final product. ${ }^{78}$ The following options attempt to create a presumption to simplify the issues in a relatively fair and litigation-saving manner. ${ }^{79}$

\section{Include a presumption that there has been a percentage passthrough:}

It [rebuttably shall be presumed] [is conclusively decided] that all changes in price due to an antitrust violation are passed along to the next level in the distribution chain as the same percentage change in price as the percentage change that was received by that level in the distribution chain.

A presumption that overcharges were passed on to the next level in the distribution chain at the same percentage increase would greatly simplify and speed up litigation, and for this reason would benefit victims. For

76. The term "presumption" can have different meanings. This Article assumes that a presumption would count as the equivalent of a type of evidence, against which the parties' evidence would be balanced. Any party desiring to overcome the presumption would have the burden of persuading the court that the presumption was unwarranted. An alternative type of presumption would be an "exploding" presumption that would lose all force in the face of any significant countervailing evidence. This type of presumption would not have much value.

77. Comm'n of the European Cmtys., White Paper on Damages for Reach of the EC Antitrust Rules $\S 2.6$ (Feb. 4, 2008), available at http://ec.europa.eu/comm/competition/antitrust/actions damages/files_white paper/whitepaper_en.pdf.

78. Professor Page does not believe that ingredient suits should be permitted even though consumers ultimately will absorb the overcharges, because "their harm cannot be calculated in practice." See Page, supra note 15 , at 741 .

79. This category is very similar to the options in Part III.C, infra, which are concerned with the split of damages between direct and indirect purchasers. However, this Part is concerned with what happens to the size of the overcharge as it gets passed from level to level. 
example, if a cartel increased prices by $20 \%$ to its direct purchasers, this would mean that every subsequent seller would be presumed also to have increased the prices of their products by $20 \%$, so the end users would be presumed to pay an additional $20 \%$ for their products. This would be the equivalent of a presumption that the retailers kept their same margin and markup; if the retailers doubled the wholesale price before the antitrust violation occurred, they would be presumed to double the wholesale price after the violation occurred.$^{80}$ This presumption could be rebuttable (one that could be overcome by either side) or it could be declared irrebuttable and conclusive.

Defendants, however, surely would consider a $100 \%$ percentage-based passthrough presumption to be too strongly proconsumer. They would, for example, object to the presumption that if the direct purchasers were overcharged by $20 \%$, they also would mark up their prices to the next level by $20 \%$. The following variation would, by contrast, favor defendants more:

2. Include a presumption that there has been a dollar-for-dollar passthrough:

There is a [presumption] [conclusive finding] that all changes in price due to antitrust violations were passed on to every subsequent level in the distribution chain as an amount equal to the same change, in dollars and cents, as the change directly caused by the antitrust violation and charged to the first purchaser of the product or service in question.

This proposal would mean that the total recoverable overcharges would not be considered to increase or decrease in amount at any subsequent level of the distribution chain. Rather the presumption would be that the existing markup in dollars and cents was simply passed to the subsequent indirect purchasers. Suppose, for example, the competitive price of a product was $\$ 1.00$ at the manufacturer level and $\$ 2.00$ at the retail level. Suppose a manufacturer cartel increased its prices from $\$ 1.00$ to $\$ 1.20$. This alternative would create a presumption that the retail price had increased by $\$ 0.20$ (from $\$ 2.00$ to $\$ 2.20$ ). This would in effect mean that the commercial intermediates had decreased their markup rule from $100 \%$ down to $83 \%$, a more conservative assumption. ${ }^{81}$

80. Many retailers rely upon rules of thumb (i.e., double the wholesale price of each product). This is simple to administer, especially in fields like grocery retailing which involve thousands of different products. In many cases it would be too difficult for the retailer to decide whether to increase the price of one of its products by $80 \%$ instead of by $100 \%$ following a price rise that might have come from an antitrust violation instead of, for example, a rise in input costs.

81. Alternatively, an IBR could contain a presumption in-between the dollar and percentage presumptions: 
3. Include a presumption that any overcharge in the ingredient or component product or service was passed on:

There [is a presumption] [shall be a conclusive finding] that each level in a product's distribution chain passed on any and all increments in its costs due to an increase in the cost of an ingredient or a component product or service that was caused by a violation of anything in this Act. This amount will be presumed to be equal to the change in the cost, in dollars and cents, of the ingredient or component product or service to its first purchaser.

This presumption could be worded in terms of dollars or in terms of percentages. For example, suppose that consumers purchased personal computers containing DRAM, and that the price of the DRAM was increased by $\$ 25$ due to illegal collusion. Suppose also that the personal computers containing the supracompetitively priced DRAM were assembled and then sold by several successive layers of sellers, and that consumers paid a precollusion price of $\$ 1,000$ for their personal computer. This type of provision could create a presumption that the final purchasers of the personal computers (who purchased their computer for, say, \$1,025) paid an extra $\$ 25$ due to the collusion of the DRAM manufacturers. ${ }^{82}$

\section{B. Proof of Damages Provisions}

Often the proof problems associated with determining standing and calculating damages in indirect purchaser cases are so formidable that the judicial system wastes considerable time and resources analyzing these issues, and the court often comes to relatively unpredictable and unreliable results. ${ }^{83}$ These problems often are especially acute in component part cases $^{84}$ and in class action cases. ${ }^{85}$ An IBR could contain presumptions or conclusions that would help to overcome these proof problems. ${ }^{86}$

There is a [presumption] [conclusive finding] that all increases in price due to antitrust violations were passed to the next level in the distribution chain as an amount in-between the cartel's dollar markup and the percentage markup imposed by the cartel.

Suppose, for example, the competitive price of a product was $\$ 1.00$ at the manufacturer level and $\$ 2.00$ at the retail level. Suppose that a manufacturer cartel increased its price from $\$ 1.00$ to $\$ 1.20$. This alternative would mandate a presumption that the retail price had increased by at least $\$ 0.20$ (to $\$ 2.20$ ), and possibly by as much as $20 \%$ (to $\$ 2.40$ ). The court would determine where, in the $\$ 0.20$ to $\$ 0.40$ range, the markup to the subsequent level was. While this approach would narrow the uncertainty for all concerned, it would not save litigation costs.

82. These are simplified and highly stylized versions of the facts contained in In re DRAM Antitrust Litigation, 536 F. Supp. 2d 1129 (2008).

83. See ABA Handbook, supra note 2, at 139-50.

84. Id. at $179-81$.

85. Id. at 151-209. See id. at 156-64 for an excellent discussion of problems involving the nume- 
1. Provide that standing should not be denied because the products or services in question were components in products or services purchased by victims.

Antitrust standing in indirect purchaser cases is governed by Associated General Contractors v. California State Council of Carpenters ${ }^{87}$ where the Court denied a union standing in part because: "the Union was neither a consumer nor a competitor in the market in which trade was restrained." ${ }^{\prime 8}$ In addition,

the nature of the Union's injury, the tenuous and speculative character of the relationship between the alleged antitrust violation and the Union's alleged injury, the potential for duplicative recovery or complex apportionment of damages, and the existence of more direct victims of the alleged conspiracyDweigh heavily against judicial enforcement of the Union's antitrust claim. ${ }^{89}$

The Associated General Contractor factors have sometimes been applied to deny victims standing because they purchased products whose major components were the subject of an antitrust violation. For example, In re Dynamic Random Access Memory Antitrust Litig. ${ }^{90}$ held:

that plaintiffs had not adequately alleged that plaintiffs' injury is "of the type the antitrust laws were intended to prevent," because the law requires that plaintiffs be participants in the relevant market alleged, and plaintiffs had failed to allege that they were either consumers or participants in the market for DRAM. Rather, they had alleged only that they were consumers in secondary markets (e.g., computer markets) incidental to the market for DRAM itself. $^{91}$

rosity, commonality, typicality, and adequacy of representation requirements.

86. Some of these provisions also could be utilized in direct purchaser legislation.

87. 459 U.S. 519 (1983).

88. Id. at 539 .

89. Id. at 545. The Court also noted: "The indirectness of the alleged injury also implicates the strong interest, identified in our prior cases, in keeping the scope of complex antitrust trials within judicially manageable limits." Id. at 543.

90. 536 F. Supp. 2d 1129 (N.D. Cal. 2008). See also In re Graphic Processing Units Antitrust Litig., 253 F.R.D. 478 (N.D. Cal 2008) (denying indirect purchaser class for component related antitrust claims).

91. In re Dynamite Random Access Memory Antitrust Litig., 536 F. Supp. at 1136 (footnote omitted) (citation omitted). Plaintiffs alleged that even though the purchasers of computers were not "participants in the relevant market for DRAM," they should be given standing so long as they were in a related market (such as the market for computers containing the affected DRAM), that was "inextricably intertwined" with the market containing the violation and also because purchasers of products containing supracompetitively priced components are "tantamount" to being in the same market as the 
If followed, this decision would deny standing in every indirect purchaser component case.

A state might well conclude that the reasoning and result of this case is contrary to the overall purpose of the antitrust laws. It is one thing for a court to conclude that unions were not meant to have antitrust standing, under the theory that unions were not the type of entity the antitrust laws were meant to protect. But in light of the consumer protection mission of the antitrust laws, ${ }^{92}$ a state might well decide that purchasers of computers containing DRAM (or other component parts whose prices were increased artificially by illegal collusion) deserve the protection of the antitrust laws. A state might be willing to tolerate some complexity in the damages analysis in order to allow final consumers to recover. These states might wish to confer standing upon these victims by the following type of provision:

A court shall award standing to every purchaser of a final product containing a component part that has been the subject of an antitrust violation without regard to whether these purchasers are consumers of, or participants in, the markets that were the subject of the antitrust violation.

This provision would not, of course, confer standing upon every indirect purchaser regardless of how remote they were from the violation because the remaining Associated General Contractor requirements (that the injury be nonspeculative, nonduplicative, and not overly complex ${ }^{93}$ ) would remain.

2. Encourage use of a class-wide basis approach for damages calculations

A state could simplify and streamline litigation by enacting a law which provides that class action damages will be figured on a class-wide basis, with damages awarded in proportion to the ratio of an individual's purchases or sales to that of the entire class. Washington, D.C. has adopted this approach:

In any class action ... the fact of injury and the amount of damages sustained by the members of the class may be proven on a class-wide basis, without requiring proof of such matters by each individual member of the class. The percentage of total damages attributable to a member of such class shall be the same as the ra-

component itself. Id. at 1137 . Their standing was, however, denied. Id.

92. See supra text accompanying notes 27-30.

93. See 459 U.S. at 543-45. 
tio of such member's purchases or sales to the purchases or sales of the class as a whole. ${ }^{94}$

A shorter alternative would be:

In any class action the class members' fact of injury and total amount of damages may be proven in the aggregate. Such aggregate damages shall be allocated among class members in a fair and equitable manner in a posttrial proceeding before the court without a jury.

The individualized proof of damages that courts can require makes classwide damages calculations overly burdensome and lengthy. This simplifying provision is meant to deal with these potentially fatal problems that effectively can deny recovery to victims of antitrust violations. ${ }^{95} \mathrm{~A}$ drawback to this approach over one that more strictly insists damages be determined on an individual basis is that under this approach some purchasers would be overrewarded while others would be underrewarded. Overall, however, this provision should help significantly from a deterrence perspective.

3. Provide that proof of a violation, or of aggregate damages to the indirect purchaser class as a whole, is sufficient to certify the class.

As noted earlier, it can be extremely difficult to show whether and to what extent damages are passed through the distribution chain. One relatively straightforward way to deal with the "fact of injury" issue component of this problem would be for a law to include a provision providing:

For purposes of class certification, the court shall conclusively find that every class member has been significantly harmed by an antitrust violation involving a final product or the components of a final product that the class members have purchased, regardless of whether these class members are direct purchasers or indirect purchasers of the products or the components that were the subject of the antitrust violation.

A milder version would allow class certification when the plaintiffs demonstrate "on a generalized basis that [the purported class's] members absorbed at least some portion of the alleged overcharges." 96 Therefore, so

94. D.C. CoDE ANN. \$ 28-4508 (2005). This section was applied successfully in Goda v. Abbott Labs., 1997-1 Trade Cas. (CCH) ๆ 71,730, at 79,141 (D.C. Super. Ct. Feb. 3, 1997).

95. See ABA Handbook, supra note 2, at 151-209.

96. B.W.I. Custom Kitchen v. Owens-Illinois, Inc., 191 Cal. App. 3d 1341, 1352 (Cal. App. Dist. 1 1987). See, for example, In re Coordinated Pretrial Proceedings in Antibiotic Antitrust Ac- 
long as plaintiffs can show that some damages were incurred by indirect purchasers as a whole, the class can be certified and plaintiffs need not prove the magnitude of harm. This provision would not, however, deal with the actual calculation of damages to particular plaintiffs.

A related issue arises when some courts refuse to certify classes because some class members passed on more of the illegal overcharges than other class members, or some class members who were direct purchasers might have been able to pass on the entirety of the overcharge. ${ }^{97}$

A court shall not deny class certification when every class member is the direct or indirect purchaser of a product or service that was the subject of an antitrust violation on the grounds that the class members have been harmed different amounts by the violation. The court shall certify the class regardless of whether particular class members absorbed all of the illegal overcharges, part or none of the illegal overcharges, or whether some class members might have marked up the illegal overcharges and increased their profits due to the illegal activity.

Suppose, for example, that a cartel raised its wholesale price from $\$ 100$ to $\$ 120$ in an industry where the retailers sold the products for $\$ 200$ before the collusion occurred. ${ }^{98}$ This provision would avoid the court getting bogged down, at the class certification stage, in the question of how much of the overcharge particular retailers absorbed, or whether they made a profit or took a loss as a result of the collusion.

4. Presume that purchasers affected by violations were harmed by a specified small amount.

The Kansas ${ }^{99}$ and the Tennessee IBRs provide that antitrust victims can recover "the full consideration or sum paid by [the person] for any goods ... the sale of which is controlled by [an illegal] combination or trust." ${ }^{100}$ These states' approaches can be thought of as equivalent to a legislative determination that prices are likely to rise by an average of approximately

tions, 333 F. Supp. 278 (S.D.N.Y. 1971), and discussion in Chris S. Coutroulis \& D. Matthew Allen, The Pass-on Problem in Indirect Purchaser Class Litigation, 44 ANTITRUST BulL. 179, 190-96 (1999).

97. See Valley Drug Co. v. Geneva Pharm., Inc., 350 F. 3d 1181, 1193 (11th Cir. 2003) ("Hanover Shoe does not hold that this net economic gain [earned by some, but not all, of the direct purchasers] must be ignored or overlooked by a court when determining whether [class certification under] Rule 23 has been satisfied.").

98. If the retailers always doubled their costs, the "cost plus" exception would apply. See supra note 2.

99. KAN. STAT. ANN. \$ 50-115 (2005) (allowing victims to recover the "full consideration" paid by victims to the illegal "combination").

100. TENN. CODE ANN. $\$ 47-25-106$ (2005) (permitting recovery of consideration as remedy for damages). 
$50 \%$ due to an antitrust violation, and then to a payment of treble damages (treble damages on a 50\% price rise would equal the supracompetitive cost of the items in question). ${ }^{101}$ The $50 \%$ presumption that Kansas and Tennessee have implicitly chosen is somewhat higher than the results of a recent comprehensive survey of cartel overcharges, which found that, historically, cartels in the United States have raised prices by an average amount of $31-49 \% .{ }^{102}$ To more accurately compensate antitrust victims, a statute containing this type of presumption should choose a figure smaller than $50 \%$ :

After a violation and the fact of damages have been proven, consumer end users of the product or service in question shall conclusively be presumed to have been injured, and the amount of the injury shall be the larger of $10 \%$ of the amount consumers paid for their products or services, or the amount by which plaintiffs can demonstrate they were injured.

A variation would create only a rebuttable presumption:

After a violation has been proven, consumer end users of the product or service in question shall be presumed to have been injured, and the amount of the injury shall be presumed to be the larger of $10 \%$ of the amount by which the violators raised or lowered the prices of the products or services in question, or the amount by which plaintiffs can demonstrate that they were injured.

Another variation specifically would apply to component parts as well:

After a violation has been proven involving a final product or any component thereof, consumer end users of the product or service in question shall be presumed to have been injured, and the amount of the injury shall be presumed to be the larger of $10 \%$ of the amount by which the violators raised or lowered the prices of the products or services in question, or the components of the products or services in question, or the amount by which plaintiffs can demonstrate they were injured.

101. Suppose a good were competitively priced at $\$ 100$, and a cartel then raised its price by $\$ 50$, to $\$ 150$. If the awarded damages were $\$ 150$, this would be treble damages (i.e., three times the $\$ 50$ increment).

102. See John M. Connor \& Robert H. Lande, How High Do Cartels Raise Prices? Implications for Optimal Cartel Fines, 80 TuL. L. REv. 513, 513 (2006), available at http://papers.ssrn.com/sol3/papers.cfm?abstract_id=787907. The range of figures comes from different data sets. 
Although the empirical results could justify a presumption of $30 \%$, these examples have instead used a $10 \%$ figure. This was chosen in part because the U.S. Sentencing Commission penalties for criminal cartel violations presume that cartels raise prices by $10 \% .{ }^{103}$ Moreover, since $79 \%$ of the cartels in the preceding survey raised prices by more than $10 \%,{ }^{104}$ this presumption also was chosen because it would be a relatively conservative one.

5. Encourage courts to use statistical sampling techniques to determine aggregate class damages.

It has been suggested that some courts are overly hostile to the use of statistical sampling techniques to determine the average amounts that class members paid in overcharges. ${ }^{105}$ Moreover, courts in at least one state, Michigan, apparently require proof of damages for every individual. ${ }^{106}$ If applied correctly, however, statistical sampling techniques can be both fair and helpful in calculating damages. ${ }^{107}$ This provision is intended to encourage the use of statistical sampling techniques whenever it would be appropriate to do so. For example, the Nevada statute provides:

Proof of such damages must be based on:

(1) Statistical or sampling methods;

(2) The pro rata allocation of illegal overcharges of sales occurring within the State of Nevada; or

(3) Such other reasonable system of estimating aggregate damages as the court may permit. ${ }^{108}$

103. See U.S. SENTENCING GuIDElines MANUAL $§ 2 R 1.1 \mathrm{cmt}$. n.3 (2005).

104. See Connor \& Lande, supra note 102, at 559.

105. ABA Handbook, supra note 2, at 182 (citing Ren v. Philip Morris, Inc., No. 00-004035-CZ, 2002 WL 1839983, at *17 (Mich. Cir. Ct. June 11, 2002)) ("In Ren v. Philip Morris, Inc., for example, a proposed class of smokers in Michigan sought to recover the allegedly inflated cost of cigarettes due to price-fixing on the part of cigarette manufacturers. Although the plaintiffs convinced the court that their expert had a valid methodology, backed up by empirical analysis, to establish impact on a class-wide basis, their class certification motion foundered on their inability to prove the amount of damages to individual smokers. . . . [T] he plaintiffs could do no more on a class-wide basis than prove the amount of damages in the aggregate."). See also Piggly Wiggly Clarksville, Inc. v. Interstate Brands Corp., 100 Fed. Appx. 296, 297 (5th Cir. 2004) ("The necessity of calculating damages on an individual basis, by itself, can be grounds for not certifying a class.”).

106. See ABA Handbook, supra note 2, at 182 (This is one way to interpret Ren v. Philip Morris.).

See also A \& M Supply Co. v. Microsoft Corp., 654 N.W.2d 572 (Mich. Ct. App. 2002).

107. See ABA Handbook, supra note 2, at 181-93.

108. NEV. REV. STAT. § 598A.160 (1999). 
The Clayton Act, Section 4D, contains a variation of this approach, but it only applies to state attorney general parens patriae actions against price fixing:

In any action under section $15 c(a)(1)$ of this title, in which there has been a determination that a defendant agreed to fix prices in violation of sections 1 to 7 of this title, damages may be proved and assessed in the aggregate by statistical or sampling methods, by the computation of illegal overcharges, or by such other reasonable system of estimating aggregate damages as the court in its discretion may permit without the necessity of separately proving the individual claim of, or amount of damage to, persons on whose behalf the suit was brought. ${ }^{109}$

Thus, this type of provision would not be unprecedented.

\section{Direct/Indirect Purchaser Damages Allocation Provisions}

Options allocating damages between direct and indirect purchasers are designed to enable indirect purchasers to sue for damages, while ensuring that the direct and indirect purchaser claims, together, total only treble damages. With caveats that will be analyzed at the end of the first Subsection, these options are not designed to increase the total amount of exposure that defendants face, overall compensation for all consumers, or deterrence. Their primary rationale is the belief that if a state permitted treble damage recoveries by both direct and by indirect purchasers, this would constitute a duplicative recovery, overcompensation to direct purchaser "victims" who were not harmed very much or at all by the violation, overdeterrence, or both. ${ }^{110}$ This is similar to the concern of some who believe that separate recovery under both federal and state law also would be excessive. ${ }^{111}$

The following approaches address the allocation of damages between direct and indirect purchasers. From a fairness or compensation perspective, allocating damages is desirable because, without an IBR, the ultimate victims of antitrust violations often are unable to recover for their injuries. Their underlying rationale was eloquently suggested by Professor Areeda:

The obvious difficulty with denying damages to consumers when buying from an intermediary is that they are injured, often more

109. 15 U.S.C. $\S 15 \mathrm{~d}(2000)$.

110. See, e.g., Clayworth v. Pfizer, Inc., 83 Cal. Rptr. 3d 45 (Cal. Ct. App. 2008) (allowing a Hanover Shoe defense in a suit under the California indirect purchaser law).

111. See Page, supra note 15. 
than the intermediary, who may also be injured, but for whom the entire overcharge is a windfall. The indirect purchaser rule greatly overcompensates intermediaries and greatly undercompensates consumers in the name of efficiency in the administration of the antitrust laws. ${ }^{112}$

\section{Hanover Shoe Repealers}

A straightforward way to implement this type of concern and make it unlikely that the direct purchasers are overrewarded is in the Washington, D.C. statute:

In actions where both direct and indirect purchasers are involved, a defendant shall be entitled to prove as a partial or complete defense to a claim for damages that the illegal overcharge has been passed on to others who are themselves entitled to recover so as to avoid duplication of recovery of damages. ${ }^{113}$

Similarly, the Rhode Island law provides:

In any action under this section the fact that a person or public body has not dealt directly with the defendant shall not bar or otherwise limit recovery. Provided, however, that the court shall exclude from the amount of monetary relief awarded in the action any amount of monetary relief which duplicates amounts which have been awarded for the same injury. ${ }^{114}$

This type of provision would permit a passing-on defense in damage actions, so it would in effect reject Hanover Shoe ${ }^{115}$ considerations.

Although it addresses the allocation of damages between direct and indirect purchasers, this type of proposal could alter the total damages paid in certain situations. For example, the direct purchasers might choose not to sue because they were too intimidated by their need to have future dealings with the violator(s), or because they passed most or all their over-

112. 2 Phillip E. Areeda, Herbert hovenkamp \& Rodger D. Blair, ANTitrust law (2d ed. 2000). Prof. Hovenkamp similarly concludes:

For direct purchasing intermediaries who pass the monopolized product on down the distribution chain the overcharge is not even a rough approximation of the injury they sustain. Rather, their injury comes mainly from lost volume. Indeed, the indirect purchaser rule often assigns the full damage action to actors who are not injured by the monopoly price at all, or who would simply be unable to prove any injury if relegated to traditional principles of damages measurement.

Herbert Hovenkamp, Antitrust and the Dominant Firm: Where Do We Stand?, at 7 (unpublished draft, on file at http://www.ftc.gov/os/comments/section2hearings/hovenkamppaper.pdf).

113. D.C. CODE ANN. $\$ 28-4509$ (b) (LexisNexis 2006).

114. R.I. GEN. LAWS $\S 6-36-12$ (g) (2006).

115. Hanover Shoe v. United Shoe Mach. Corp., 392 U.S. 481 (1968). 
charges to the next level. Under these circumstances this provision would permit indirect purchasers to recover, so the total damages paid by defendants would increase.

Alternatively, total damages typically paid by defendants, and the total amount of deterrence against future anticompetitive behavior, could at times diminish under this type of IBR. When both direct and indirect purchasers are deciding whether to sue, the uncertainty over whether any recovery obtained would go to the direct purchasers, to the first level of indirect purchaser, to a subsequent indirect purchaser, or to two or more levels in the distribution chain in some unpredictable ratio, could cause each class of purchasers to decline to file suit. Both direct and indirect purchasers might be less likely to invest the considerable amount of time and money needed in light of the very real prospect that the court could award some or even all of the fruits of their efforts to the other class(es) of purchasers. Any IBR likely to cause contentious litigation between various classes of purchasers inadvertently could discourage private actions, shield violators, and ensure that no aggrieved party received any compensation. Ironically, a statute like that proposed recently by the ABA which provides, in effect, "never mind at the outset which class of plaintiff gets the money, the court can straighten that out after it determines liability and damages, $" 116$ could lead to fewer lawsuits and therefore less compensation and deterrence. The ensuing fight over the damages allocation also would constitute wasteful and potentially lengthy litigation, further diminishing and delaying the amounts that will be awarded to each class of victim.

The following options are intended to help prevent this problem (and accomplish other tasks as well) by making a presumption or conclusive finding as to which layer in the distribution chain absorbed the overcharge.

2. Include a rebuttable presumption that all of the damages accrue to the final purchasers.

For example, the Feb. 2004 ABA Discussion Draft contains the following:

It shall be presumed, in the absence of proof to the contrary, that the total illegal overcharge incurred by a direct purchaser was passed on to the ultimate purchaser, who made such purchase not for resale and in a form that has not been substantially modified at the time of such purchase; otherwise a defendant shall be entitled to prove as a partial or complete defense to a claim for damages that the illegal overcharge has been passed on to others who are 
themselves entitled to recover so as to avoid duplication of recovery of damages. ${ }^{117}$

The European Union has proposed a presumption that the entire overcharge was passed through to end users. ${ }^{118}$ A relatively simple law doing this could be worded as follows:

It shall be presumed that the ultimate purchasers (who bought not for resale) incurred, absorbed, and ultimately paid all of the damages caused by the antitrust violation. All other purchasers in the chain of distribution can, however, attempt to rebut this presumption and prove that they absorbed part or all of these damages.

The presumption that ultimate consumers pay all the damages would be desirable from a compensation perspective because final purchasers often are the real payers of the majority of the overcharges. It also should reduce uncertainty over which class will receive the damages, and this should encourage the victims to sue. Its disadvantage, of course, is that injured direct purchasers would be less likely to receive any recovery, and this could be undesirable because the direct victims are sometimes harmed and because they often have the strongest incentive to file suit. Moreover, there could be significant litigation over whether this presumption should be overcome. Since such litigation can be both wasteful and lengthy and could undermine both levels' incentives to sue, it has obvious disadvantages, and for this reason there would be an advantage to making the presumptive conclusive.

3. Award Damages to Direct Purchasers and to Indirect Purchasers in a Predetermined Manner.

Potential fights between direct and indirect purchasers could be minimized if the awarded damages were split in a way that presumptively awarded a fixed percentage of total (trebled) damages both to direct purchasers, and also to indirect purchasers. This predetermined split is justified from a fairness or compensation perspective because it seems likely that in many or most cases both direct and indirect purchasers absorbed some of the overcharges. The predetermined split approach also is appropriate from a deterrence perspective because it should give each class of purchaser at least some incentive to sue, probably more than an approach that awarded them an uncertain percentage. Moreover, sometimes the di-

117. Id.

118. Comm'n of the European Communities, White Paper on Damages for Breach of the EC Antitrust Rules, Section 2.6 at $7-8$ (Feb. 4, 2008), http://ec.europa.eu/comm/competition /antitrust/actionsdam ages/files_white_paper/whitepaper_en.pdf. 
rect purchasers will have more of an incentive to sue, ${ }^{119}$ while other times the indirect purchasers have the greater incentive. ${ }^{120}$ This type of provision ensures that the better situated plaintiff always will have an incentive to litigate. ${ }^{121}$ It would also minimize litigation time and costs.

For example, a statute could contain a rebuttable presumption that direct purchasers paid at least a third of the damages and that indirect purchasers also paid at least a third of the damages. When trebled, this would mean that direct and indirect purchasers each would receive at least single damages: ${ }^{122}$

It shall be presumed, in the absence of proof to the contrary, that the direct purchasers incurred at least one third of the damages, and for this reason the direct purchasers shall recover at least one third of the awarded damages. It also shall be presumed, in the absence of proof to the contrary, that the indirect purchasers incurred at least one third of the damages, and for this reason the indirect purchasers shall recover at least one third of the awarded damages. The final third of the damages shall be awarded by the Court to those purchasers most likely to have absorbed the damages. All computed damage amounts shall be trebled before they are awarded.

This proposal is worded in terms of damages rather than overcharges because some cases might involve monopsony. Another option is to split the damages 50/50:

It shall be presumed, in the absence of proof to the contrary, that the direct purchasers incurred one half of the damages, and for this reason the direct purchasers shall recover one half of the awarded damages. It also shall be presumed, in the absence of proof to the contrary, that the indirect purchasers incurred one half of the damages, and for this reason the indirect purchasers shall recover one half of the awarded damages. The damage amounts

119. See infra notes $321-37$ and accompanying text.

120. Id.

121. These cases usually are brought on a contingent fee basis, involving considerable risk, expenses, attorney time, and years of delay before any recovery. See generally Lande \& Davis, supra note 11 . The only way to safeguard victims is to be cognizant of the position of their would-be lawyers, who are unlikely to file suit unless they can predict, in advance of the litigation, that the class they represent stands a reasonable likelihood of a significant recovery. There can, of course, never be a way to guarantee any recovery to victims or compensation to their would-be attorneys since many cases are unsuccessful and many plaintiffs' attorneys do not deserve compensation. Nevertheless, a presumptive or guaranteed split of the recovery between different classes of victims could help to provide the necessary incentives for the victims and their attorneys.

122. A jurisdiction especially interested in making sure that injured parties were compensated could add a prejudgment interest provision. See infra Part III.D (Provision 1). 
shall be calculated as being equal to three times the amount by which the violators illegally raised or lowered prices to the first purchaser.

Another variation would award $1 / 3$ of the damages to the direct purchasers and $2 / 3$ to the indirect purchasers.

4. Provide for a conclusive, rather than presumptive, allocation of damages.

Conclusively allocating damages would avoid a great deal of potentially contentious, lengthy, and costly litigation. It would also allow direct and indirect purchasers to focus their efforts against the law violator, rather than against each other. Without a guarantee-not merely a presumption-that each class of purchaser will receive at least some of the recovery, neither direct nor indirect purchasers may have sufficient incentive to undertake the significant investment of time and money required to pursue a lawsuit. ${ }^{123}$ This approach would be efficient and highly desirable from a deterrence perspective: both direct and indirect purchasers would have a strong incentive to sue. One drawback to this approach is that it could lead to some purchasers being overrewarded while other purchasers were underrewarded:

It conclusively shall be found that the direct purchasers absorbed one-half of the damages, and for this reason the direct purchasers shall recover one half of the awarded damages. It also shall conclusively be presumed that the indirect purchasers absorbed half of the damages, and for this reason the indirect purchasers shall recover half of the awarded damages. All computed damage amounts shall be trebled before they are awarded.

A variation would be to split the damages in a $1 / 3$ to $2 / 3$ ratio. Another alternative would award both direct and indirect purchasers single damages, and allow the court to determine which purchasers are most entitled to the remaining single damages:

It conclusively shall be found that the direct purchasers incurred at least one third of the damages, and for this reason the direct purchasers shall recover at least one third of the awarded damag-

123. In general, class certification might be harder for indirect purchasers because of remoteness issues. If true, this is another reason why indirect purchasers should be given an incentive to sue through the assurance of a recovery of part of the treble damages. Some believe, however, that when the litigation is over a product (like a prescription drug) that does not change form through the chain of distribution, it should be no more difficult to get a class certified than a direct purchaser case. Similar arguments apply to the damages phases of direct and indirect purchaser actions. 
es. It also conclusively shall be found that the indirect purchasers incurred at least one third of the damages, and for this reason the indirect purchasers shall recover at least one third of the awarded damages. The final third of the damages shall be awarded by the Court to those purchasers most likely to have absorbed the damages. All computed damage amounts shall be trebled before they are awarded.

A significant complication arises from the fact that there often will be more than one level of indirect purchasers that could make an arguable claim to have absorbed some or all of the overcharges. ${ }^{124}$ Not only is it often extremely difficult to allocate the ultimate absorption of overcharges between direct and indirect purchasers; it also is likely to be difficult to allocate the ultimate payment of these overcharges between different levels of indirect purchasers. The necessary litigation to determine which level paid exactly how much of the overcharges could discourage the filing of these actions, which could lead to less deterrence. Moreover, the expenses involved in this litigation could diminish the total amount of compensation likely to be received by aggrieved consumers. One solution to these problems, when there is more than one level of indirect purchasers, would be to award each level single damages. A statute doing so could be worded as follows:

In cases where there is only one level of indirect victims (i.e., where the ultimate consumers of the products or services in question deal directly with the firms that dealt with the antitrust violators), it shall be conclusively presumed that the direct and the indirect victims each absorbed half of the damages. In these cases the direct victims shall recover half of the awarded damages, and the indirect victims also shall recover half of the awarded damages. The damage amounts shall be calculated as three times the amount by which the violators illegally raised or lowered prices to the first purchaser.

In cases involving more than one level of indirect victims, the total damages caused by the violator's or violators' direct overcharges

124. This complication was stressed by Bennett Rushkoff, Chief, Consumer and Trade Protection Section, Office of the Corporation Counsel, District of Columbia at a March 25, 2004 program on antitrust damages sponsored by the D.C. Bar Association's Antitrust, Trade Regulation, and Consumer Affairs Section.

Rushkoff also pointed out that an approach which awarded each level of purchaser some damages would have the advantage of ensuring continued general support for the antitrust laws from direct purchasers, an important class of businesses. He noted that frequently many or most indirect purchasers are consumers, and without some kind of damages redress possibility for direct purchasers the political support for antitrust from an important sector of the business community could decrease. 
or undercharges shall be computed. This will be the amount by which the violators illegally raised or lowered prices to the first purchaser. This amount will be awarded to the direct purchasers and also to each level of indirect purchasers. These amounts shall not, however, be trebled.

If one's highest priority is optimal deterrence, this alternative has merit because it would give each level of purchaser in the chain of distribution some damages, and therefore some incentive to sue. If one's highest priority is optimal compensation, however, the ultimate buyer at the bottom of the distribution chain should receive the bulk of the claim because they are the only level without the ability to pass on an overcharge.

Under this alternative each level of purchaser would have an incentive to detect and sue the cartel because each class would be guaranteed some of the recovery. By contrast, without a conclusive presumption, there is a possibility that no class will sue out of fear that the award would go to another class of victim. Another advantage of a conclusive presumption is that litigation costs would be minimized because the different victim classes would not litigate against one another over who really paid how much of the damages. ${ }^{125}$

This approach would mean that on occasion the total amount of damages awarded could total more than threefold. Depending upon the number of levels of indirect purchasers in the relevant market, damages could total fourfold or more. Such a proposal might be thought of as a compromise between the preferences of those who believe that total damages should never exceed traditional antitrust treble damages, and those who believe that the nominal "treble damages" awarded under the antitrust laws today actually constitute only single damages. ${ }^{126}$ This later group believes that, from the perspective of optimal deterrence, and in light of the omission of prejudgment interest and the other adjustments that should be made to the current so-called "treble damages" awarded under the antitrust laws, ${ }^{127}$ this type of approach would ensure that the total awarded damages level would be closer to true treble damages.

A downside of this approach is that awarding each level of purchasers single damages, regardless of whether, or the extent to which, the purchasers were actually harmed, some purchasers would be overcompensated while others would be undercompensated. Another downside would be that the size of the defendants' payments will depend upon the number of classes of indirect purchasers that buy their product or service. This

125. This approach also might alleviate some notice problems. A conclusive allocation of damages among different classes of purchasers could make disputes over who gets notice less of an issue.

126. See Lande, Single Damages?, supra note 27, passim.

127. Id. 
surely will strike many as odd or unfair: some defendants would pay treble damages, but others would pay fourfold or fivefold damages, depending only upon whether the product or service in question were sold to one, two, or three levels of indirect purchasers. The number of levels of purchasers should not be an issue from a deterrence or fairness perspective.

An alternative that eliminates this problem would be to presume or conclusively find that every level in the distribution chain was harmed equally, and then to split the trebled damages among the various levels in the distribution chain:

The total damages caused by the violator's or violators' direct overcharges or undercharges shall be computed. The awarded damage amounts shall be calculated as three times the amount by which the violators illegally raised or lowered prices to the first purchaser. This result will be split equally among each level of direct or indirect purchaser, so that each level receives an equal amount.

Another alternative would award single damages to the direct purchasers, single damages to the final level of indirect purchasers, and direct the court to award the final single damages to whichever level or levels are most entitled to this relief:

The total damages caused by the violator's or violators' direct overcharges or undercharges shall be computed. The total awarded damage amounts shall be calculated as equal to three times the amount by which the violators illegally raised or.lowered prices to the first purchaser. It shall be conclusively presumed that the direct victims and the final level of indirect victims are each entitled to single damages.

In cases involving only one level of indirect purchasers, the indirect purchasers will receive a second award of single damages.

In cases involving more than one level of indirect purchasers, the Court shall make another single damages award to either the direct purchasers, the final level of indirect purchasers, or to any other level of indirect purchasers, in whatever ratio the Court believes is appropriate. These amounts shall correspond to the Court's determination as to which level of purchaser absorbed the damages from the violation.

5. Have the court designate a "presumptive lead plaintiff." 
Barak D. Richman \& Christopher R. Murray propose handling the allocation of damages between direct and indirect purchasers by having the court designate a "presumptive lead plaintiff," a solution modeled after the approach often used in securities litigation. ${ }^{128}$ They propose:

Following the initiation of an antitrust suit and after appropriate notice is given, other parties claiming injury may join, after which the action becomes closed. At this point, the court ... will designate a lead plaintiff. The court's designation would be directed by two guiding principles; first, a presumption in favor of the party who initiated the suit, and second, a presumption in favor of the party claiming the greatest damages. ${ }^{129}$

They explain that the first factor is designed to "enhance the incentives for potential plaintiffs to bring suit" and the second presumption "is designed to identify the party best capable of handling the litigation and representing the preferences of the joined plaintiffs." 130 Despite these advantages, this approach has significant drawbacks. First, the plaintiff claiming the most damages would not necessarily be the plaintiff that actually was harmed the most. Nor would the party first filing suit be likely to have been harmed the most. ${ }^{131}$ Also, given the complexities involved in the passthrough calculations, it is not likely to be readily or quickly apparent which class of purchasers actually absorbed most of the overcharges. This can only be determined after a lengthy investigation. Finally, whichever class of plaintiff is designated "lead plaintiff" would have an incentive to be unfair to the other classes of plaintiffs. For all these reasons the direct/indirect purchaser situation is likely to be different from that involving securities cases.

128. Richman \& Murray, supra note 31 .

129. Id. at 106-07 (footnotes omitted).

130. Id. at 107 .

131. Direct purchasers would be likely to be the first ones to notice an illegal price rise, but this would not mean they were the ones ultimately to absorb most of the price rise.

An analogous "race to the courthouse" alternative was promulgated by Prof. Dennis Carlton, while he was an AMC Commissioner. Prof. Carlton suggests permitting suits by direct purchasers only, and allowing indirect purchasers to file only if no direct purchaser filed within a specified period of time. In these cases there could only be indirect purchaser suits. See AMC report, supra note 51.

While attractive in many respects, this approach also has significant drawbacks. It assumes, without evidence, that direct purchasers have the greatest incentive to sue. It also would give direct purchasers an incentive to file quickly even if they have no incentive to pursue the litigation seriously. If the direct purchasers were not the class harmed significantly and fear retaliation from powerful suppliers, they would have an incentive to settle on easy terms. This would ingratiate them to the supplier-violators, but result in both inadequate overall deterrence and inadequate compensation for the true victims. 


\section{Additional Provisions}

There are a number of additional provisions that a state might want to include in IBR legislation. These provisions could be important regardless of whether the indirect purchasers were simply given an additional right to sue for damages, or whether the damages awarded to indirect purchasers would be subtracted from the damages awarded to direct purchasers. These provisions, moreover, could also be included in direct purchaser statutes, especially where the state was especially interested in having an antitrust law that provides strong deterrence against anticompetitive conduct and in fully compensating victims.

\section{Award prejudgment interest.}

Prejudgment interest is not awarded under the federal antitrust statutes and, as a practical matter, ${ }^{132}$ is only theoretically available under a few state statutes. ${ }^{133}$ This omission could, however, be cured by a statute providing that:

Damages for injuries by reason of anything forbidden in this Act shall include interest thereon computed from the date on which such injury is sustained, at a rate that will provide the present value of such damages, and the cost of suit, including a reasonable attorney's fee.

The award of prejudgment interest, even if made in addition to treble damages, would not be a "duplicative" form of recovery. It is simply a way to account for inflation and the time value of money, and it is necessary to make victims whole. Prejudgment interest also should help to foster optimal deterrence; if a lawbreaker steals $\$ 1.00$ and is only forced to give back $\$ 1.00$ eight years later, ${ }^{134}$ it will have made a tidy profit from the transaction..$^{135}$ For this reason many believe that a prejudgment interest provision is nonduplicative, fair, and reasonable.

132. Most courts currently can award prejudgment interest in situations involving defendants' bad faith or as a sanction for dilatory behavior, but this apparently never has happened in an antitrust case. For example, Section 16750 of California's damages law provides that a plaintiff shall "recover three times the damages sustained by him or her, interest on his or her actual damages pursuant to Section 16761 ... . CAL. BuS. \& PROF. CODE $\$ 16750$ (West 2008). However, Section 16761 provides that this will only happen when "the court finds that the award of interest for such period is just in the circumstances." CAL. BUS. \& PROF. CODE $§ 16761$ (West 2008). The appropriate circumstances include the filing of meritless motions, assertions, or defenses. Id.

133. See, e.g., TEX. BUS. \& COM. CODE ANN. § 15.21(a) (Vernon 2005).

134. The average of the estimates made by several prominent scholars suggests that the average cartel case lasts between seven and eight years. See discussion in Lande, Single Damages?, supra note 27 , at $130-34$.

135. For example, $\$ 100.00$ in 2000 would have the same buying power as $\$ 125.03$ in 2008 . See Bureau of Labor Statistics, CPI Inflation Calculator, http://www.bls.gov/data/inflation_calculator.htm 
One could argue that damage awards are trebled in part to account for the lack of prejudgment interest. It seems much more likely, ${ }^{136}$ however, that the trebling actually is performed to account for the difficulty of detecting and proving violations. Under the standard optimal deterrence model, if only one-third of cartels are detected, convicted, and made to pay damages, then damages should be trebled to insure that collusion is not profitable. ${ }^{137}$ Including prejudgment interest would make awards reflect the present value of the harms inflicted. Antitrust damages could then truly act as a more effective deterrent against anticompetitive behavior. ${ }^{138}$ While the logic underlying prejudgment interest applies equally to direct purchaser recoveries, a prejudgment interest provision might be of special interest to jurisdictions contemplating a statute that only awards single damages to indirect purchasers. A much more limited approach would limit prejudgment interest to suits brought by state attorneys general.

As an alternative to explicitly adding a prejudgment provision, an IBR instead could allow purchasers to recover for the diminished value of their business. This could be similar to a prejudgment interest provision:

A claimant may, at its election, use the diminished value of its business or property caused by the antitrust violation, instead of the amount of overcharges or undercharges paid, as the proper measure of damages. This diminution in value shall be computed as the difference between the value of the victim's business or property at the time of the violation, and the value of the victim's

(last visited Feb. 9, 2010). One way to avoid litigation over the proper prejudgment interest rate would be for the law instead to set the prejudgment interest rate as the same interest rate as that provided by statute for postjudgment interest.

136. Inflation rates were relatively low when the Clayton Act was passed. See Bureau of Labor Statistics, Consumer Price Index, ftp://ftp.bls.gov/pub/special.requests/cpi/cpiai.txt (last visited Feb. 9, 2010). Moreover, litigation was not as lengthy. See Richard A. Posner, A Statistical Study of Antitrust Enforcement, 13 J.L. \& ECON. 365, 374-81 (1970). Thus, accounting for prejudgment interest seems very unlikely to have been a significant concern.

137. For the standard optimal deterrence framework, see William M. Landes, Optimal Sanctions For Antitrust Violations, 50 U. CHI. L. REV. 652, 656 (1983).

The multiplier used in calculating antitrust damages should be larger than one because not all violations are detected and proven. From the perspective of optimal deterrence, if damages and fines only total actual damages, firms would be undeterred from committing violations. For this reason most agree that there should be some kind of multiplier. If we only catch and successfully prosecute $1 / 3$ of all cartels, for example, then threefold damages are appropriate to achieve optimal deterrence. Of course, no one knows whether we catch more or less than 1/3 of all antitrust violations. But, since a multiplier of more than 1 is appropriate, and no one can demonstrate that antitrust should instead use a multiplier of 2 or 4 , we usually assume, without much evidence, that only $1 / 3$ of all cartels are detected and proven, and therefore, a multiplier of 3 is appropriate. Optimal damages therefore are assumed to be equal to the net harm to others times 3 .

Lande, Antitrust Damage Levels, supra note 7, at 335-37 (citations omitted).

138. Without prejudgment interest the "treble" damages multiplier would be closer to double damages. See Lande, Single Damages?, supra note 27, at 134-36. 
business or property at the time of the damages judgment, insofar as this difference was caused by the antitrust violation.

Since the value of a business normally will increase simply due to inflation, this type of provision could be an implicit way to effectively bring a rough form of prejudgment interest into the pretrebling base. It might face less opposition than an explicit prejudgment interest provision. This type of damages sometimes is awarded currently, but this provision should make its award more common. ${ }^{139}$ It would not, however, benefit consumer victims.

2. Increase the statute of limitations to Eight years.

The current federal statute of limitations for antitrust damages actions is four years, ${ }^{140}$ and state statutes of limitations differ. There is evidence, however, that the average cartel lasts for roughly seven to eight years. ${ }^{141}$ Sometimes the illegal overcharges that arise during the early years of a cartel's activity can be recovered through one of the exceptions to the statute of limitations ${ }^{142}$ Nevertheless, sometimes a relatively short statute of limitations will immunize early cartel activity. A state might want to make its IBR's statute of limitations as least as long as the length of the average cartel.

3. Encourage recovery of the "umbrella effects" 143 of market power.

A cartel or monopoly cannot effectively earn supracompetitive profits unless prices rise for substantially the entire affected market. ${ }^{144}$ If a cartel or monopoly with significantly less than a $100 \%$ market share raises prices, it would be difficult for these prices to stay elevated very long unless most of the nonviolating firms in the market implicitly went along with the price increase, at least to some extent. ${ }^{145}$ If noncolluding firms reacted independently to the changed price levels, their conduct would be legal.

139. See generally ABA MODEL JURY INSTRuctions IN Civil ANTITRUST CASES DAMAGES INSTRUCTION No. 2, at F-12 (2005).

140. 15 U.S.C. $\S 15 b(2005)$.

141. See Lande, Single Damages?, supra note 27, at 130-34.

142. The most common is the fraudulent concealment exception. Id. at 136-38.

143. This is the name commonly given for price rises of products sold by nonviolating firms when these price rises are caused by the illegal activity. For example, OPEC never produced even $70 \%$ of the free world's supply of oil. Yet, when OPEC raised prices, prices also increased for the oil sold by noncartel members. See Robert H. Lande, Five Myths About Antitrust Damages, 40 U.S.F. L. REV. 651, 654 (2006) [hereinafter Lande, Five Myths], available at http://papers.ssrn.com/sol3/papers .$c f m$ ?abstract id $=1263478$. Moreover, the price of fuels that were partial substitutes for oil, such as natural gas, also rose. Id. Any price rises that took place outside the affected relevant market, however, would probably be too complicated to assess, so they will not be analyzed further in this Article.

144. HERBERT HOVENKAMP, ANTITRUST LAw \2002f6 (vol. 2, 2d ed. 2005).

145. This also could occur if the cartel is able to price-discriminate effectively. For an explanation and analysis of the welfare effects of price discrimination, see Kirkwood \& Lande, supra note 42. 
Nevertheless, these elevated prices are not serendipitous: they are necessary for the violators' cartel to function effectively. The violators can only earn supracompetitive profits if the other prices in the market also rise.

These "umbrella effects" of market power are another harm caused by the anticompetitive activity. This provision would make the law violators, and only the law violators, responsible for umbrella damages. The firms that did not engage in the illegal behavior would not have to pay damages due to the elevated prices on the products they sold.

Many respected scholars, including Professors Areeda and Hovenkamp, have concluded that antitrust violations should be considered the direct cause of their umbrella effects and that injured plaintiffs should be able to collect for these overcharges from the violators. ${ }^{146}$ Yet, the umbrella effects of market power are unusually difficult to prove, and defendants can assert that they are remote, speculative, incidental, or indirect. Because of these proof problems, umbrella effects rarely, if ever, are awarded in antitrust cases. ${ }^{147}$ Courts are split over whether plaintiffs should even have standing to attempt to prove their existence. ${ }^{148} \mathrm{~A}$ statute that encourages their award could be worded as follows:

When a firm or firms that violate any of the antitrust laws engage in illegal activity that affects prices, there is a presumption that the illegal behavior caused prices to change for all sales in the affected relevant market, including the sales of nonviolating firms that are in this market. The changed prices of nonviolating firms shall be considered the direct, proximate, and nonspeculative result of the violator(s) activities and shall be attributed to the activities of the violator(s). The violators shall pay these damages to the violation's victims.

A presumption that umbrella effects of market power exist and should be proximately attributed to the violators' actions would simplify proof problems and lead to greater deterrence. To avoid litigation, the "presumption" could instead be "conclusive." A more limited approach would limit the use of the presumption or conclusion to suits brought by state attorneys general.

4. Provide that plaintiffs (or, alternatively, only the state attorney general) can recover for the allocative inefficiency harms of illegally acquired or maintained market power.

146. See PHILlip E. AREedA \& Herbert HovenKamp, ANTITRUST LAW $\{337.3$ (Supp. 1992).

147. The author is not aware of any final antitrust verdict awarding umbrella effects.

148. Id. 
"Allocative inefficiency" is the economic term that describes the general harm to the welfare or efficiency of the economy caused by the reduction in output that accompanies the exercise of market power. ${ }^{149}$ It represents the lost "consumers' surplus" or total worth of goods and services in a society that would have arisen but for the supracompetitive pricing. Allocative inefficiency harms in no respects duplicate or overlap with the wealth transfer effects of antitrust violations. ${ }^{150}$ Moreover, most leading conservative scholars, such as Judge Frank Easterbrook, ${ }^{151}$ believe that allocative inefficiency is another harm from market power that, in addition to the wealth transfer effects, should be included in antitrust awards. ${ }^{152}$

A major problem with even considering the inclusion of allocative inefficiency harms in an antitrust award, however, is that it is an amorphous and difficult-to-understand concept that sounds like it could be only theoretical. ${ }^{153}$ It is difficult even to find an intuitive, nontechnical way to describe it, although at least one court seemed to understand the term. ${ }^{154}$ Nevertheless, it might be significant that the current Nevada statute provides that, in addition to normal antitrust damages, the Nevada Attorney General is empowered to sue "[a]s parens patriae, with respect to direct or indirect damages to the general economy of the State of Nevada or any political subdivision thereof." ${ }^{n 55}$ Are the "direct or indirect damages to the general economy" of the state the same as the "allocative inefficiency" effects of market power? The term used in the Nevada statute could be a nontechnical way of describing the concept of allocative inefficiency. We are, however, unaware of any court interpretations directly on point. ${ }^{156}$

149. A more detailed explanation of the concept of allocative inefficiency is complex. See Lande, Single Damages?, supra note 27, at 119-22, 152-53; Frank Easterbrook, supra note 39, at 454-55.

150. The wealth transfer effects of market power consist only of the money transferred from the victims to the violators due to the illegally acquired market power, not of the economic inefficiency it creates. See Lande, Single Damages?, supra note 27, at 152-53.

151. See Easterbrook, supra note 39, at 454-55.

152. Id. See also Landes, supra note 137.

153. It is, however, routinely taught in first or second year economics courses, and also in standard antitrust law classes. See, e.g., E. ThOMas Sullivan \& Herbert Hovenkamp, ANTITRuSt Law, Policy and Procedure: Cases, Materials, Problems 7-17 (LexisNexis 5th ed. 2003).

154. See Island Tobacco v. R. J. Reynolds Indus., 513 F. Supp. 726, 740 n.22 (D. Haw. 1981) ("Where independent firms agree to fix prices, they reduce the number of economic units with market price discretion. Allocative inefficiency occurs where, for example, open market discretion is eliminated and firms agree to fix prices above the marginal cost of production, which is the level toward which prices tend to move if many firms within the market freely compete with each other.").

155. NEV. REV. STAT. § 598A.160(1)(b) (2005).

156. However, Hawaii v. Standard Oil Co., 405 U.S. 251, 262-64 (1972) held that a state may not recover for harm to its general economy, although the concept of allocative inefficiency was never explicitly discussed in this opinion:

Thus, $\S 4$ permits Hawaii to sue in its proprietary capacity for three times the damages it has suffered from respondents' alleged antitrust violations. The section gives the same right to every citizen of Hawaii with respect to any damage to business or property. Were we, in addition, to hold that Congress authorized the State to recover damages for injury to its general economy, we would open the door to duplicative recoveries.

This court gave the reason why this recovery could not be permitted under the antitrust laws: 
Another drawback to including this damages item is that it is difficult to trace exactly who suffers this effect because allocative inefficiency harms such a diverse group within the economy. ${ }^{157}$ Perhaps due to these proof problems, apparently no plaintiff has ever recovered for the allocative inefficiency harms of market power. ${ }^{158} \mathrm{In}$ light of the immense problems in identifying precisely who is harmed by allocative inefficiency, perhaps only state attorneys general should even be allowed to attempt to recover for the allocative inefficiency harms of market power, in parens patriae suits. They would, after all, represent the consumers of their states in such actions, so a recovery for the allocative inefficiency harms of market power in these situations would be appropriate.

As a practical matter, it would be extremely difficult for any plaintiff, even a state attorney general, to prove the size of the allocative inefficiency harms since this would require calculating the shape of the demand curve for the product or service in question. ${ }^{159}$ It therefore would be crucial to have a statutory conclusion (or at least a presumption) as to its size. The resolution of this issue was suggested by Judge Easterbrook, who wrote that in general the allocative inefficiency harms of market power are equal to $50 \%$ of its wealth transfer effects. ${ }^{160} \mathrm{~A}$ more conservative ap-

\footnotetext{
"Measurement of an injury to the general economy, on the other hand, necessarily involves an examination of the impact of a restraint of trade upon every variable that affects the State's economic healthifa task extremely difficult, 'in the real economic world rather than an economist's hypothetical model.'" Id. at 263 n. 14 (citation omitted).

157. For example, suppose a cartel raised the price of a product from $\$ 1.00$ to $\$ 1.50$. A consumer who would have purchased the product for $\$ 1.25$ was harmed by $\$ 0.25$ due to the cartel's actions. But it would be extraordinarily difficult for this consumer to prove that they gladly would have purchased it if the product had been priced at $\$ 1.00$, and would reluctantly have purchased it at $\$ 1.25$, but did not purchase it (or purchased a smaller quantity) because the cartel raised the price to $\$ 1.50$.

158. The author is not aware of any final antitrust verdict awarding any sum for the allocative inefficiency effects of market power.

159. See Easterbrook, supra note 39.

160. Judge Frank Easterbrook explained why he believes that the allocative inefficiency effects of market power are $50 \%$ as large as the wealth transfer effects:

In the simple case of linear demand and supply curves, the allocative loss is half the monopoly overcharge, so a multiplier of 1.5 is in order. These curves doubtless are not linear, but legal rules must be derived from empirical guesses rather than exhaustive investigation. The multiplier of 1.5 thus may be a rough approximation of the lower bound. It takes care of the fact that the nonbuyers do not recover damages. A further multiplier is necessary to handle the improbability of proving liability. As uncertainty and the difficulty of prosecution increase, so should the multiplier. From the violator's perspective, "treble" damages really are double the starting point of overcharge plus allocative loss, and thus trebling the overcharge is appropriate when the chance of finding and successfully prosecuting a violation is one in two.

Id. at 454-55.
}

The U.S. Sentencing Commission might have estimated that the allocative inefficiency effects of market power are as large as the transfer effects, although the evidence for this is ambiguous. It wrote:

It is estimated that the average gain from price-fixing is 10 percent of the selling price. The loss from price-fixing exceeds the gain because, among other things, injury is inflicted upon consumers who are unable or for other reasons do not buy the product at the higher prices. Because the loss from price-fixing exceeds the gain, subsection (d)(1) provides that 20 per- 
proach would be to presume that the allocative inefficiency harms are only one-third of the transfer effects. If we assume the allocative inefficiency effects of market power are one-third as large as the transfer effects, when these two figures are added (to 1.33 times the overcharge) and then trebled, the result would total four times the original damages. This same presumption would be equally appropriate in both direct and indirect purchaser actions. This could be accomplished by a provision such as the following:
When states sue in their capacity as parens patriae they shall also recover for the general harm to the welfare [efficiency] of the economy caused by [the reduction in output] caused by the anti- trust violation. This damage will be [presumed to equal] [conclu- sively found to equal] one third of the overcharges caused by the antitrust violation. This amount will be trebled and the result will be awarded.

The words in the brackets are optional.

\section{Add an explicit cy pres provision.}

Often the entirety of a class recovery in a private suit or in a parens patriae action cannot feasibly be distributed to individual class members. In these cases the court is required to formulate an alternative distribution of the remaining funds. The cy pres doctrine permits these residual funds to be distributed for the indirect benefit of class members or other closely related purposes. ${ }^{161}$ The doctrine originated in the common law and today California appears to be the only state that has a statute unequivocally authorizing cy pres distribution in class action cases. ${ }^{162}$

cent of the volume of affected commerce is to be used in lieu of the pecuniary loss under $\S 8 \mathrm{C} 2.4(\mathrm{a})(3)$.

U.S. SENTENCING GUIDELINES MANUAL $\$ 2$ R1.1 cmt. n.3 (2002).

161. This Subpart draws upon and condenses information contained in Albert A. Foer's forthcoming paper: Enhancing Competition Through the Cy Pres Remedy: Suggested Best Practices (Am. Antitrust Inst., Working Paper No. 07-11, 2007), available at http://www.antitrustinstitute.org/archives/files/aai- Cy Pres, Foer, best practices wkg paper 1107_112920072232.pdf.

In addition, Herbert Newberg \& Alba ConTe, NeWBerg on Class ACTIONS $\$ 10.17$ (3d ed. 1992) discusses how the courts have the general equity powers to determine how to distribute the funds. "Where no legal claim to settlement benefits exists, a court can exercise its equitable powers to distribute the remaining funds." In re Motorsports Merch. Antitrust Litig., 160 F. Supp. 2d 1392, 1393 (N.D. Ga. 2001) (citing Powell v. Georgia-Pacific Corp., 843 F. Supp. 491, 495 (W.D. Ark. 1994)).

162. CAL. CIV. PROC. CODE $\S 384$ (a) provides: "It is the intent of the Legislature in enacting this section to ensure that the unpaid residuals in class action litigation are distributed, to the extent possible, in a manner designed either to further the purposes of the underlying causes of action, or to promote justice for all Californians." Section 384(b) provides that

the court shall determine the total amount that will be payable to all class members, if all class members are paid the amount to which they are entitled pursuant to the judgment. The 
The cy pres doctrine permits unclaimed or residual class action funds to be put to their next best use for the benefit of class members, and the courts have broad discretion to determine how to direct the funds to their next best use and to identify qualified recipients. ${ }^{163}$ However, there have been many settlements where courts have distributed leftover funds to charitable organizations not in any way related to the plaintiffs' original claims. For example, in Superior Beverage Co. v. Owens-Illinois, ${ }^{164}$ the court held that its broad equitable powers permitted the use of funds for other public interest purposes by educational, charitable, and other public service organizations. The court distributed the funds to nonprofit legal groups, law schools, and an art museum. ${ }^{165}$ In In re Motorsports Merchandise Antitrust Litigation, a price fixing case, the court approved a cy pres distribution to charities not in any way related to the underlying antitrust issues, including The Make-A-Wish Foundation and The American Red Cross. ${ }^{166}$

In light of the purpose of the cy pres doctrine and the possibility that the judge will use this money to further his or her pet charities or those of the attorneys involved, ${ }^{167}$ it might be desirable to specifically direct the court to order that all of the leftover funds should be used to enhance antitrust enforcement: ${ }^{168}$

If, in a class action or parens patriae case filed under this Section, including settlements, it is not feasible to return any part of the recovery to the injured purchasers, the Court shall order that the residual funds be applied to benefit the specific injured class of purchasers and/or improve antitrust enforcement on behalf of consumers in general. This shall include enhancing the antitrust enforcement budget of the State Attorney General and underwriting

court shall also set a date when the parties shall report to the court the total amount that was actually paid to the class members. After the report is received, the court shall amend the judgment to direct the defendant to pay the sum of the unpaid residue, plus interest on that sum at the legal rate of interest from the date of entry of the initial judgment, to nonprofit organizations or foundations to support projects that will benefit the class or similarly situated persons, or that promote the law consistent with the objectives and purposes of the underlying cause of action, to child advocacy programs, or to nonprofit organizations providing civil legal services to the indigent.

163. See Kevin M. Forde, What Can a Court Do with Leftover Class Action Funds? Almost Anything!, 35 JUDGES' J. 19, 19 (1996).

164. 827 F. Supp. 477,479 (N.D. Ill. 1993).

165. Id. at $480-87$.

166. 160 F. Supp. 2d 1392, 1396 (N.D. Ga. 2001).

167. A few states have a formal procedure for selecting recipients, but most do not. Moreover, the State Attorney General when acting in a parens patriae capacity, unlike the judge or the private class action attorneys, usually is an elected official who is politically accountable, and presumably is in the best position to decide how to allocate funds in the public interest.

168. It is, however, possible that some state constitutions may prohibit setting up "special purpose" funds, and that this could be considered to constitute such a fund. 
antitrust-enhancing activities of nonprofit education or research organizations.

As an alternative, the residual funds could instead escheat to the state treasury. This escheatment might have the added effect of helping to increase state support for antitrust.

6. Add a collateral source provision.

In appropriate cases defendants sometimes point out that third parties or collateral sources pay purchasers directly, or reimburse them for certain products. ${ }^{169}$ Defendants sometimes argue that in these cases purchasers suffered no "injury" that is cognizable under the antitrust laws, despite any higher prices that are caused by an antitrust offense. ${ }^{170}$ This defense is especially likely to arise in antitrust cases involving pharmaceuticals ${ }^{171}$ and other products covered by insurance or by Medicaid. We are unaware of any antitrust damages cases that have recognized this defense, and the common law does not favor the defense on the theory that the wrongdoer should not gain because the consumer has paid for insurance. ${ }^{172}$ Nevertheless, a state might want to include a collateral source provision:

Any person injured due to any violation of this Act shall recover the full amount of all damages awarded under this Act, even if such injured person receives payment for or is reimbursed for these damages, directly or indirectly, by an insurance policy, governmental unit, charity, or other collateral source.

Any defendant able to escape payment because its purchasers already recovered all or part of its damages from, for example, an insurance company, would be undeterred from engaging in antitrust violations. In addition, this provision would prevent defendants from introducing further complications and delays into cases involving pharmaceuticals, automobile replacement parts, and other products and services. It could, however, lead to subrogation claims by third parties.

7. Include a savings provision:

169. See, e.g., Goda v. Abbott Labs, 1997-1 Trade Cas. (CCH) \71,730, at 79,145-46 (D.C. Super. Ct. Feb. 3, 1997) (rejecting the collateral source defense).

170. Id.

171. Defendants can argue that third party payer claims were derivative of consumer claims and thus too remote, but that consumers were not injured because they had prescription coverage. If defendants prevail with these arguments, defendants will collect the overcharge, but no one has standing to complain about it.

172. Id. 
The remedies contained in this Section have always been available under applicable state law and/or state Constitutional provisions. This provision is intended to codify existing law.

This provision could be added to IBRs passed in states that arguably already have an IBR-type provision in an existing "little FTC Act," fraud or consumer protection statute, or in the state constitution. Otherwise, the addition of an explicit IBR could inadvertently immunize conduct carried out prior to its passage. An alternative would be for the statute to explicitly apply to all cases filed after the effective date regardless when the conduct occurred.

\section{A PROPOSED MODEL ILLINOIS BRICK REPEALER}

If they had the power to design the United States antitrust system from scratch, very few members of the antitrust community would retain the current system, which allows suits on the federal level only by direct purchasers, and permits suits on the state level by indirect purchasers in some, but not all, jurisdictions. ${ }^{173}$ Nevertheless, this status quo might remain in effect for the foreseeable future. Accordingly, states without effective IBRs should be encouraged to protect victimized state consumers and businesses by enacting an effective new IBR, or amending an existing limited or ineffective statute, rather than wait for a federal solution.

Whether a state decides to enact an IBR and, if it does, the provisions it decides to include, depend critically upon its goals and priorities. For example, some do not believe the antitrust laws should have as a high priority compensating victims, ${ }^{174}$ and it is not surprising that these people are generally opposed to enacting any form of state IBRs. ${ }^{175}$ Others have as a very high priority designing a system that precludes any chance whatsoever of "duplicative" recoveries and, not surprisingly, they tend to design systems that favor defendants. ${ }^{176}$

One way to describe a state or federal decision whether to enact an IBR and, if so, which type of IBR to implement, is in terms of Types I, II, and III error. Normally, analysts employ a framework focused only on Type I and Type II error; that is, most frameworks of decisionmaking are

173. See Prud'homme \& Cooper, supra note 21, at 676 ("Like antitrust defense counsel, many antitrust plaintiffs' counsel believe the current system is costly, inefficient, and unnecessarily complex. However, plaintiffs' counsel typically differ with defense counsel on the appropriate solution.").

174. See, for example, Page, supra note 15 , at 18-24, 26-27, who focuses on deterrence and would eliminate compensation considerations from IBRs.

175. Id. See also Dennis Carlton, Commissioner, Remarks at the Antitrust Modernization Commis-

sion Meeting (May 8, 2006) (transcript available at http://govinfo.library.unt.edu/amc/pdf/meetings/060508_Revised_Deliberation_Transcript.pdf).

176. See ABA Section of Antitrust Law, Response to Antitrust Modernization Commission's June 12, 2006 Request for Public Comment on Civil Remedies, at 2, 3 (2006). 
designed to minimize the chances that beneficial conduct is prevented, and also to minimize the chances of permitting undesirable conduct. ${ }^{177}$

When a jurisdiction is deciding whether to enact an IBR, Type I error should include situations involving overdeterrence, where a cartel or monopoly would be forced to pay damages so large that firms would avoid undertaking beneficial conduct out of fear that the conduct would result in unjustified or excessive penalties. It also would include overcompensation of victims, or "compensation" to purchasers that have not been harmed by anticompetitive conduct. ${ }^{178}$ Indeed, this type of overcompensation is probably the primary cause of overdeterrence from an IBR.

By contrast, Type II error would include the costs of failing to discourage cartels and other anticompetitive behavior. It also would include undercompensation of actual victims of the illegal behavior. Not surprisingly, undercompensation of true victims can lead to underdeterrence of anticompetitive behavior.

In addition to Types I and II error, states considering an IBR should also consider a third type of error. Type III error occurs when the system created to decide the issues leads to increased costs to businesses, consumers, enforcers, or decisionmakers. ${ }^{179}$ In the IBR context, these costs include litigation expenses by both plaintiffs' and defendants' attorneys and their expert witnesses, the costs arising from delays, and also the value of additional corporate time spent on these issues. It also includes the undesirable effects on society arising from any increased business uncertainty, and the increased cost to the judicial system which imposes additional costs on taxpayers. Quantitatively, Type III error can be very significant, ${ }^{180}$ and any policy that ignores it runs a substantial risk of departing from an optimal result.

The table below compares three alternative state IBR policies with respect to Types I, II, and III error. It assumes a status quo which permits suits only by direct purchasers. The three alternatives are no IBR, an IBR that does not contain presumptions to simplify litigation, and an IBR that contains significant presumptions (discussed throughout this Article) that would simplify litigation.

In general, any attempt to minimize one type of error requires increasing at least one of the others. Ideally, we would quantify each of the errors involved and choose a policy that minimized the sum of all three (subject only to a Congressional decision to value one type of error more highly

177. See Alan A. Fisher \& Robert H. Lande, Efficiency Considerations in Merger Enforcement, 71 CAL. L. REV. 1580, 1670-71 (1983).

178. This overcompensation should be figured on a "net" basis. Even if many direct purchasers currently are being overcompensated, the overcompensation would not be increased by an IBR.

179. See Fisher \& Lande, supra note 177, at 1670-71 (introducing the concept of Type III error; defining and using these terms in a related antitrust context; merger enforcement).

180. Id. 
than the others). In fact, we have very little data on how large any of the three errors would likely be under any of the alternatives. Because of this lack of data, reasonable people, with different assumptions about the relative magnitudes of the errors, can differ as to the optimal enforcement policy.

Comparison of Error Magnitudes Under Alternative Approaches To The Enactment of IBRs (relative to the status quo, with no IBR)

Proposal

No State IBR

IBR without presumptions to simplify litigation IBR with presumptions to simplify litigation
Type I Error

Zero

Maximizes

Maximizes
Type II Error

Maximizes

Minimizes

Minimizes
Type III Error

Zero

High

Low

No one can know what the actual numbers in this table would be. However, it appears that Congress, when it enacted the antitrust laws, seemed to weigh Type II error much more heavily than Type 1 error. ${ }^{181}$ It therefore appears that the optimal solution would be for states to enact an IBR, but one that contains a number of presumptions that would minimize litigation expenses and delays, and also the uncertainty for all concerned.

The alternative this Article will propose has as its highest priority minimizing Type II error (i.e., maximizing deterrence against anticompetitive behavior, and maximizing the compensation of victims). It also seeks to minimize Type III error (by employing presumptions to simplify litigation and making it more predictable) ${ }^{182}$ By contrast, it has given a much lower priority to the Type II error goal of ensuring that no purchasers are ever overrewarded; it could occasionally overreward some plaintiffs who were indirect purchasers and did not absorb the entirety of the illegal overcharges. Occasional overcompensation for some of these plaintiffs is the cost of providing an incentive for more classes of purchasers to sue. This Article's proposal also could result in a theoretical Type I error risk that some lawbreakers would pay more than effective treble damages and thereby will be overdeterred ${ }^{183}$ and less likely to engage in beneficial conduct. However, this same risk has existed in many states since soon after

181. See the discussion in Kirkwood \& Lande, supra note 42 passim.

182. Another benefit of this Article's proposal is that, by simplifying and lowering the costs and time required for litigation, it also will maximize certainty for all parties involved. To the extent direct and indirect purchaser litigation is consolidated into one proceeding, the percentage of the award going for litigation expenses should decreaselanother Type III error benefit.

183. Overdeterrence is especially unlikely in the large percentage of private suits that are filed against cartels that have been criminally convicted of illegal collusion. For information about many of these cases, see Lande \& Davis, supra note 11 . Overdeterrence against such firms is only a remote possibility. 
Illinois Brick was decided, and during this almost thirty year period it has never occurred. ${ }^{184}$ Indeed, since antitrust damage awards do not include prejudgment interest or account for a host of other factors, ${ }^{185}$ the risk that someday a cartel might pay more than true treble damages should be acceptable.

The most important elements of such legislation could be contained in a small number of relatively brief provisions:

1. Amend the law to create a right of recovery for indirect purchasers that would not affect the recovery of direct purchasers:

The plaintiff in any action commenced hereunder may sue for and recover treble the damages sustained. Such action may be brought by any person who is a citizen or resident of this State who is injured in their business or property by reason of anything forbidden or declared unlawful by this Act, regardless of whether such person dealt directly or indirectly with the defendant. This remedy is an additional remedy to any other remedies provided by law, and this remedy shall not diminish or offset any other remedy. ${ }^{186}$

2. Give standing to purchasers of component parts:

A court shall award standing to file suit under this Act on behalf of every purchaser of a final product containing a component part or service that has been the subject of an antitrust violation, without regard to whether these purchasers are consumers of, or participants in, the markets that were the subject of the antitrust violation. ${ }^{187}$

3. Include a rebuttable presumption that overcharges, in dollars and cents, are passed to final indirect purchasers:

There is a strong presumption that all changes in price due to antitrust violations were passed on to every subsequent level in the distribution chain as an amount equal to the same change, in dol-

184. There has never been even one well-documented example of a cartel, monopoly, or other group of antitrust violators paying more than three times the damages caused by their violation. For a discussion, see Lande, Antitrust Damage Levels, supra note 7, at 333-39. See also Prud'homme \& Cooper, supra note 21 , at 684 (" [We have found the possibility of duplicative federal and state treble damages payments] in the almost thirty years since llinois Brick, to be entirely hypothetical. To the Authors' knowledge, there has not been a single documented instance where a defendant has been subject to suit by direct and indirect purchasers and been required to pay more than treble damages.").

185. See Lande, Single Damages?, supra note 27.

186. See supra Part I.A (discussing its advantages and disadvantages).

187. See supra Part III.B (discussing its advantages and disadvantages). 
lars and cents, as the change directly caused by the antitrust violation and charged to the first purchaser of the product or service in question.

This presumption also applies to any and all changes in price due to a change in the cost of an ingredient or a component product or service that was caused by a violation of anything in this Act. This amount will be presumed to be equal to the change in the cost, in dollars and cents, of the ingredient or component product or service to its first purchaser. ${ }^{188}$

4. Find that end user purchasers have been harmed by a specified small amount:

After a violation has been proven, end users of the products or services in question conclusively shall be found to have been injured, and the amount of the injury shall be found to be the larger of either $1.10 \%$ of the amount by which the violators raised or lowered the prices of the products or services in question, or 2 . the amount by which plaintiffs can demonstrate they were injured. This finding shall be made regardless whether the violation occurred in the market containing these final products or services, or was in an ingredient, component, or input market. ${ }^{189}$

5. Add findings or conclusions that simplify class certification litigation:

In any class action, . . . the fact of injury and the amount of damages sustained by the members of the class may be proven on a class-wide basis, without requiring proof of such matters by each individual member of the class. The percentage of total damages attributable to a member of such class shall be the same as the ratio of such member's purchases or sales to the purchases or sales of the class as a whole.

Damages may be proved and assessed in the aggregate by statistical or sampling methods, by the computation of illegal overcharges, or by such other reasonable system of estimating aggregate dam-

188. See supra Part III.C (discussing the pros, cons, and other effects of this and other types of pass-on presumptions). This provision is a compromise because it uses the milder "presumption" (albeit modified with the word "strong") instead of making a finding, and also because it uses the "dollars and cents" markup, rather than the percentage markup approach.

189. See supra Part III.C (discussing its advantages and disadvantages). The selected provision should greatly simplify litigation in a large number of cases. See id. 
ages as the court in its discretion may permit, without the necessity of separately proving the individual claim of, or amount of damage to, persons on whose behalf the suit was brought. ${ }^{190}$

6. Include a prejudgment interest provision:

Damages for injuries by reason of anything forbidden in this Act shall include interest thereon computed from the date on which such injury is sustained, at a rate equal to the statutory rate for postjudgment interest in this State, and the cost of suit, including a reasonable attorney's fee. ${ }^{191}$

7. Encourage the State Attorney General to participate as an advisor to the judge in consumer class action cases:

Plaintiffs shall notify the Attorney General about the filing [alternatively, the certification] of any class action containing purchasers from that State that involves antitrust allegations. All parties in these cases shall send copies of all filings in these cases to the Attorney General. The Attorney General may, at his or her discretion, intervene or file an amicus brief that gives the presiding Judge his or her opinion as to the appropriateness of any proposed settlement of the case. ${ }^{192}$

8. In addition to allowing private suits, permit the state Attorney General to file damages actions on behalf of any aggrieved indirect or direct purchasers in his or her state:

The Attorney General may bring a civil action for any violation of the provisions of this chapter ... [a]s parens patriae of the persons residing in this state, with respect to damages sustained directly or indirectly by such persons, or ... as a representative of a class ... of persons ... who have been damaged directly or indirectly .... ${ }^{193}$

9. Add a cy pres provision:

190. See supra Part III.B.

191. See supra Part III.D (discussing the reasons for this provision).

192. See supra Part II (discussing its advantages and disadvantages).

193. NEv. REv. STAT. ANN. § 598A.160(1)(a) (LexisNexis 2005). This would be a supplement to, but not a replacement for, private rights of action. Many states already give their attorney general this right. See supra Part II. 
If, in a class action or parens patriae case filed under this Section, including settlements, it is not feasible to return any part of the recovery to the injured purchasers, the Court shall order that the residual funds be applied to benefit the specific injured class of purchasers and/or to improve antitrust enforcement on behalf of consumers in general. This shall include enhancing the antitrust enforcement budget of the State Attorney General and underwriting antitrust-enhancing activities of nonprofit education or research organizations. ${ }^{194}$

Although the preceding provisions together embody most of what an effective IBR should contain, as has been noted throughout this Article, opinions vary greatly as to what constitutes an optimal IBR. Some states will prefer alternative solutions that are more restrictive, ${ }^{195}$ and some states might prefer a remedy that is more encompassing. ${ }^{196}$ This Article has proposed a Model IBR with full knowledge that it will not be appropriate for every state to enact. Ideally it would be enacted on the federal level, but this possibility should not discourage states from developing and enacting their own legislation.

194. See supra Part III.D (analyzing cy pres issues).

195. For example, some states might decide to permit only their attorney general to sue on behalf of indirect purchasers. See supra Part II.

196. For example, this Article's suggested Model State IBR does not include a provision for either the umbrella effects or the allocative inefficiency effects of market power. See supra Part III.D (discussing the reasons why these provisions should be included). 